\title{
Fictitious States, Effective Control, and the Use of Force Against Non-State Actors
}

\author{
By \\ Brian Finucane*
}

This Article examines how states respond to violent non-state actors operating from "fictitious" states. Fictitious states possess international legal personality but they lack effective control over their territories and populations. Examples of fictitious states include Pakistan, Yemen, and Somalia. These entities are not states that "failed" but territories where the paradigm of traditional statehood is inapplicable.

In contrast to much of the literature analyzing the use of force vis-à-vis contemporary threats, this Article contends that the global security problem posed by fictitious states is more fundamental than that posed by terrorism or failed states. The modern threat emanating from fictitious states is most vividly illustrated by Al Qa'ida; however, violent non-state actors have long exploited territories beyond the writ of any central government. Often, when threatened by these non-state actors, victim states have responded with transborder force.

This Article discusses key incidents over the past two centuries that elucidate the extensive and under-appreciated history of a state's right to exercise defensive force against non-state actors in ungoverned territory. Such incidents include US intervention in Spanish Florida, British intervention in New York State, and Russian intervention in Mongolia. These incidents show that: (1) there is a well established customary right of self-defense of victim states that is not contingent upon the consent of host states; and (2) this customary right was preserved by the United Nations (UN) Charter.

The challenge for the international order is to identify the conditions under

* Yale Law School, J.D. 2010; Oxford University, DPhil, 2008; Cornell University, A.B. 2003. The author is an attorney-adviser at the U.S. Department of State. This Article was written prior to the author's employment at the Department of State and any views expressed herein are solely those of the author, and are not necessarily those of the United States or the Department of State. The author is grateful to Sigrun Kahl, Oona Hathaway, Sean Murphy, and Ashley Deeks for their comments on earlier drafts. 
which a victim state may act in self-defense against a non-state actor. The state practice and legal claims investigated in this Article demonstrate that the principles governing such action are the same as those that apply to state-to-state selfdefense: necessity and proportionality. This Article explains how these principles structure the use of force against non-state actors and delineates the battlefield in a conflict between a victim state and a non-state actor, such as the United States' conflict with Al Qa'ida.

\section{INTRODUCTION}

Targeted killing of Al Qa'ida fighters in the ungoverned regions of Pakistan, Yemen, and Somalia exposes a lacuna in the treaty-based regime governing the use of force. ${ }^{1}$ If, as the International Court of Justice claims, the UN Charter's prohibition on the use of force is the "cornerstone" of the modern international system, this cornerstone rests on a foundation of sand. ${ }^{2}$ The Charter embodies a security framework intended to regulate relations between effective states - states possessing effective control over people and territory. Taken by itself, such a state-centric regime is incomplete. However, this treaty-based regime is supplemented by a body of customary law regulating the use of force against non-state actors operating from ungoverned territory. This Article examines this body of customary law, focusing on the principles that can be drawn from state practices and legal claims over the past two centuries. These customary principles define, in part, the effective state's inherent right of self-defense.

Effective states exercising control over their nominal territories and populations, i.e., "positive sovereignty", are not the natural form of political organization. ${ }^{3}$ The ideal of the Westphalian state-system posits adjacent territorial entities, each ruled by central authorities exercising effective control over populations and territories within defined borders. This exists, most of the time, in much of northern Eurasia and in neo-European settlement colonies, such as the United States, Australia, and Canada.

However, this model is the exception rather than the rule in much of the

1. U.N. Charter art. 2, para. 4 ("All Members shall refrain in their international relations from the threat or use of force against the territorial integrity or political independence of any state, or in any other manner inconsistent with the Purposes of the United Nations").

2. Armed Activities on the Territory of the Congo (Dem. Rep. Congo (DRC) v. Uganda), Judgment, 2005 I.C.J. 116, 148 (Dec. 19) ("The prohibition against the use of force is a cornerstone of the United Nations Charter"); Military and Paramilitary Activities (Nicar. v. U.S.), 1986 I.C.J. 14, 153 (June 27) (separate opinion of President Singh) ("the very cornerstone of the human effort to promote peace in a world torn by strife").

3. Georg Schwarzenberger, A Manual of International Law 38 (1950) (describing positive sovereignty as the "claim to have control over persons, things and territory"); ROBERT JACKSON, QUASI-STATES, SOVEREIGNTY, INTERNATIONAL RELATIONS AND THE THIRD WORLD 11, 29 (1990) (discussing the concept of positive sovereignty and its relationship with negative sovereignty). 
rest of the world. "Fictitious states" lack central authority capable of exercising effective control over a substantial fraction of the territory and population within their internationally recognized boundaries, making their sovereignty a legal fiction. $^{5}$ Nonetheless, fictitious states are entitled to the legal right to noninterference, or "negative sovereignty." Fictitious states include many of the post-colonial entities of sub-Saharan Africa (e.g., the Democratic Republic of Congo), as well as countries in Latin America (e.g., Peru), and South and Central Asia (e.g., Pakistan). In extreme cases, fictitious states, such as Somalia, may control a seat at the United Nations but virtually none of their own territory.

In contrast to much of the literature analyzing the use of force vis-à-vis contemporary threats, this Article contends that the global security problem is more fundamental than terrorism or failed states. To analyze the security dilemma facing governments as one of "terrorism" is a misdiagnosis. ${ }^{7}$ The global security problem is not limited to a specific tactic, whether employed by state or non-state actors. Nor is the problem limited to the exceptional cases of completely "failed" states, such as Somalia. ${ }^{8}$ Indeed, the notion of a "failed" state presupposes, usually incorrectly, that an effective state existed or should have existed in the first place. Instead, the fundamental challenge to international order is that the constitutive unit of the international system is a fiction in many parts of the world. Perhaps a majority of the entities with seats at the United Nations do not control some or all of their territory and population. ${ }^{9}$ The effective state and the monopoly of the state over internationally significant violence cannot be taken for granted.

The disjunction between positive and negative sovereignty that characterizes fictitious statehood represents a persistent threat to the international order. The US 2002 National Security Strategy emphasized that "America is now

4. See JACKSON, supra note 3; JefFery HerbSt, StATES AND POWER IN Africa (2000); Christopher Clapham, The Global-Local Politics of State Decay, in When STATES FaIL 77 (Robert I. Rothberg ed., 2004); Miguel Angel Centeno, Blood and DebT: War and the Nation-State IN LATIN AMERICA (2002).

5. This term overlaps with Jackson's term "quasi-state" but is broader. See JACKSON, supra note 3 , at 1 . I use the term fictitious state to emphasize that their reality is a legal fiction.

6. SCHWARZENBERGER, supra note 3, at 38 ("In its negative aspect State sovereignty means independence from outside interference").

7. See, e.g., Christian Tams, The Use of Force against Terrorists, 20 EUR. J. INT'L L. 359 (2009).

8. See, e.g., Gerald B. Helman \& Steven R. Ratner, Saving Failed States, 89 ForeIGN POLICY 3 (1992-93); Robert I. Rotberg, The Failure and Collapse of Nation-States: Breakdown, Prevention, and Repair, in When STATES FAIL: CAUSES AND CONSEQuences 1 (Robert I. Rotberg ed., 2004); Ben N Dunlap, State Failure and the Use of Force in the Age of Global Terror, 27 B.C. INT'L \& COMP. L. Rev. 453 (2004); John Yoo, Fixing Failed States, Working Papers, International Legal Studies Program, UC Berkeley, Feb. 13, 2010, available at http://www.escholarship.org/uc/item/6hb33156.

9. See JACKSON, supra note 3; HERBST, supra note 4; Clapham, supra note 4; CENTENO, supra note 4. 
threatened less by conquering states than we are by failing ones." 10 Secretary of Defense Robert Gates reiterates this conclusion by noting that "[i]n the decades to come, the most lethal threats to the United States' safety and security . . are likely to emanate from states that cannot adequately govern themselves or secure their own territory. Dealing with such fractured or failing states is, in many ways, the main security challenge of our time." 11

This threat has only increased with the political upheaval that has accompanied the Arab Spring. The fall of former Egyptian President Hosni Mubarak's regime has led to lawlessness in the Sinai Peninsula that anti-Israeli fighters have exploited. ${ }^{12}$ Yemeni militants have taken advantage of the weakening of the Saleh regime to expand their territorial control. ${ }^{13}$ Most worrying for the United States, the fall of Colonel Muammar Gaddafi and the failure of the Libyan rebels to adequately exercise control of the country has led to the dispersal of an unknown quantity of Man Portable Air Defense Systems (colloquially known as MANPADs) from Libyan arms depots. ${ }^{14}$

The collision between the legal fiction and the reality of statehood reveals that, taken by itself, the UN Charter's regime governing the use of force is incomplete. Such a framework does not adequately promote global security because it does not account for fictitious states and non-state actors. Fictitious

10. National Security Council, The National Security Strategy of the United States of America (Sept. 15, 2002), available at http://georgewbush-whitehouse.archives/gov/nsc/nss/2002/index.htm [hereinafter National Security Strategy].

11. Robert M. Gates, Helping Others Defend Themselves: The Future of U.S. Security Assistance, FOREIGN AFFAIRS, May 2010, at 1, available at http://www.foreignaffairs.com/articles/66224/robert-m-gates/helping-others-defend-themselves.

12. Heba Afify \& Isabel Kershner, A Long Peace Is Threatened in Israel Attack, N.Y. TIMES, Aug. 19, 2011 (describing how the "northern Sinai has devolved into a lawless outpost"), available at http://www.nytimes.com/2011/08/20/world/middleeast/20egypt.html?pagewanted=all.

13. Laura Kasinov, In Yemen One Islamist Dead, But the Battle Goes On, N.Y. TimES, Oct. 2, 2011, available at http://www.nytimes.com/2011/10/03/world/middleeast/in-yemen-one-islamistdead-many-more-in-arms.html?_r=1\&scp=12\&sq=yemen $\% 20+\% 20$ saleh $\% 20+\% 20$ control\&st=cse. (noting that Islamic militants "control large areas of territory in the country's restive south"); see also ANgel RABASA, ET AL., UngOVERNEd TERRITORIES: UNDERSTANDING AND REDUCING TERRORISM RISKS (2007) (a RAND Corporation analysis of the security threats present in several ungoverned areas for the United States Air Force); A Lonely Master of a Divided House, THE ECONOMIST, Apr. 24, 2010, at 45 (describing Yemen in the context of Al Qa'ida activity and multiple insurgencies as "famously hard to govern. Yet even if the power of Mr. Saleh's state has seldom extended beyond Yemen's main towns, roads and oilfields, it is remarkable he has maintained even a semblance of control").

14. David D. Kirkpatrick, Egypt's Arrests of Smugglers Show Threat of Libya Arms, N.Y. TiMES, Oct. 13, 2011, available at http://www.nytimes.com/2011/10/14/world/middleeast/egyptarrests-groups-smuggling-weapons-from-libya.html?scp $=2 \&$ sq $=$ libya $\% 20+\% 20$ missiles $\& s t=c s e$ (describing the smuggling of missiles from Libya to the Sinai); Eric Schmitt \& Kareem Fahim, U.S. Sending More Contractors to Secure Libya's Weapons Stockpile, N.Y. TIMES, Oct. 14, 2011, available at http://www.nytimes.com/2011/10/15/world/africa/us-sending-contractors-to-secure-libyasweapons.html ("The State Department is sending dozens of American contractors to Libya to help that country's fledgling efforts to track down and destroy heat-seeking antiaircraft missiles looted from government stockpiles that could be used against civilian airliners"). 
states are incapable of binding through international agreements the territory and people over whom they lack effective control. There is a need for a framework or residual mechanism that accounts for the existence of ungoverned territory. As this Article explains, such an effective, complementary regime already exists in customary international law.

This Article proceeds in four parts. Part I briefly analyzes the state-centric use of force principles embodied in the UN Charter. In particular, it examines the concepts of statehood and sovereignty, and, especially, the effective control of people and territory upon which the Charter rests.

Part II explains why a strict state-centric regime has never been viable. Drawing upon empirical insights from comparative politics and anthropology, it demonstrates that the traditional statehood of international law is nothing more than a legal fiction in much of the world. Part II argues that the disjunction between the state-centric security regime and the current threat environment has been exacerbated by the redefinition of statehood during decolonization, when statehood became an entitlement rather than a factual condition. This Part concludes with an analysis of the International Court of Justice's decision in Armed Activities on the Territory of the Congo (Dem. Rep. Congo v. Uganda), 2005 I.C.J. 168 (Dec. 19). Armed Activities serves as a case study of the inadequacy of a state-centric security paradigm in a world of fictitious states and non-state actors.

Part III places contemporary security threats in historical and legal perspective by examining the extensive and under-appreciated history of cross-border defensive measures premised upon state ineffectiveness. This Part shows that, notwithstanding the state-centric regime of the UN Charter, many interventions against non-state actors were accepted as lawful by the governments of major powers even before 9/11. It examines in detail the legal claims made by governments and demonstrates that these claims both explicitly and implicitly invoke state weakness as a basis for intervention.

Part IV proposes a framework for governing the international use of force that balances the danger posed by interstate conflict and opportunist intervention with the growing threat posed by non-state actors and ungoverned territories. Drawing upon pre-Charter state practice and opinio juris, Part IV details how customary principles of necessity and proportionality should structure the use of force against non-state actors in the future. It explains how these principles establish geographic restrictions upon the recourse to force and why differentiation between state and non-state actors is necessary. It concludes with a reconsideration of the armed attack requirement of Article 51 of the UN Charter. 
I.

The Assumption: The StATE-Centric REgime

The victorious Allies created the United Nations to "maintain international peace and security," that is, peace and security between states. ${ }^{15}$ To this end, the UN Charter imposes a general prohibition in Article 2(4) on the use of force by Members against other states. ${ }^{16}$

Both explicitly and implicitly, the Charters of the United Nations and $\mathrm{NATO}^{17}$ embody a state-centered use of force paradigm. Drafted in the final months of the interstate conflict of the Second World War, the UN Charter reflects international efforts to prevent a repeat of the then ongoing war. The interstate focus of the Charter is clear in its Preamble, which emphasizes the horrors of the World Wars. ${ }^{18}$ The peace and security at stake was international (used here to mean between two or more states). ${ }^{19}$

Article 51, however explicitly preserves a narrow exception to the prohibition on Members' unilateral use of force against other states: "Nothing in the present Charter shall impair the inherent right of individual or collective selfdefense if an armed attack occurs against a Member of the United Nations...."20 The scope of this exception has been vigorously contested ever since, especially as concerns its application to non-state actors. ${ }^{21}$

This Article argues that the customary right of self-defense preserved by Article 51 unequivocally encompasses defensive action taken against non-state actors. These customary principles of self-defense supplement and complement the state-centric regime embodied in the UN Charter.

However, before turning to the scope of the exception in Article 51, it is

15. U.N. Charter art. 1, para 1 ("We the peoples of the United Nations determined to save succeeding generations from the scourge of war, which twice in our lifetime has brought untold sorrow to mankind ... ").

16. U.N. Charter art. 2, para. 4 ("All Members shall refrain in their international relations from the threat or use of force against the territorial integrity or political independence of any state, or in any other manner inconsistent with the Purposes of the United Nations").

17. Report of the Committee on Foreign Relations on the North Atlantic Treaty, S. REP. No. 81-8, at 13 (1st Sess. 1949) (interpreting the "armed attack" requirement for collective self-defense under Article 5 of the North Atlantic Treaty as "an attack by one State upon another").

18. U.N. Charter, pmbl.; Ann-Marie Slaughter \& Bill Burke-White, An International Constitutional Moment, 43 HARV. INT'L L. J. 1,1 (2002) ("The framers of the U.N. Charter were responding to two worlds wars, countless interstate wars, and indeed centuries in which the primary threat to international peace and security was the aggressive use of force by one state against another").

19. IAN BROWNLIE, INTERNATIONAL LAW AND THE USE OF ForCE By StATES 279 (1963) (arguing that even if a non-state actor could mount an armed attack, "[t]he incursions of armed bands can be countered by measures of defense which do not involve military operations across frontiers").

20. U.N. Charter art. 51 (emphasis added).

21. See, e.g., Mark A. Drumbl, et al., Self-defense in an Age of Terrorism, 97 AM. Soc'Y INT'L L. Proc. 141 (2003); John Yoo, Using Force, 71 U. CHI. L. REV. 729 (2004); Nicholas Rostow, International Law and the Use of Force: A Plea for Realism, 34 YALE J. INT'L L. 549 (2009); Sean D. Murphy, Protean Jus Ad Bellum, 27 BERKELEY J. INT'L L. 22 (2009). 
first necessary to explain the general prohibition against the unilateral use of force. The logic of the use of force principles embodied in the Charter rests upon a very specific understanding of the nature of the state.

\section{A. Effectiveness: The Essence of Statehood in International Law}

Underlying the Charter's state-centric security framework is the assumption that, within each internationally recognized state exists some central authority in control of all internationally significant armed forces within that territory. This assumption stems from the traditional conception of statehood. During the late nineteenth and early twentieth centuries, statehood was a matter of fact. ${ }^{22}$ The critical quality of a state from the standpoint of internal and external security was effectiveness. ${ }^{23}$

State effectiveness is defined by: 1) effective control of territory, and 2) effective control of people. ${ }^{24}$ The effective control of territory and the exclusion of external private armed groups is primarily a function of a state's coercive capability. Such capability is measured by the strength of its police and military forces $v i s-\grave{a}$-vis non-state actors, the latter seeking a safe haven within the state's territory for themselves. The effective control of people implies "social control" 25 and "effective authority" 26 and is in part a function of a state's coercive capability. However, control in all but the most authoritarian entities is also contingent upon legitimacy and shared identity. ${ }^{27}$ A state's effective control of people prevents the indigenous development of independent armed groups. Effective control of people and territory are mutually reinforcing as a state's legitimacy enhances its coercive capabilities and vice versa.

22. J.L. BRIERLY, THE LAW OF NATIONS 137 (6th ed. 1963) ("Whether or not a new state has actually begun to exist is a pure question fact").

23. James Crawford, The Creation of States in InTERnational LaW 77 (1979) ("The traditional criteria for statehood were based almost entirely on the principle of effectiveness. The proposition that statehood is a question of fact derives strong support from this equation of effectiveness and statehood. In other words, although it is admitted that effectiveness in this context is a legal requirement, it is denied that there can exist legal criteria for statehood not based on effectiveness").

24. Id. at 42 (Explaining that traditionally "international law defines 'territory' not by adopting private law analogies of real property, but by reference to the extent of governmental power exercised, or capable of being exercised, with respect to some area and population").

25. Joel Migdal, Weak States, Strong Societies 22-23 (1988) ("State social control involves the successful subordination of peoples own inclinations of social behavior or behavior sought by other social organizations in favor of the behavior prescribed by state rules . . . . Getting the population to obey the rules of the state rather than the rules of the local manor, clan or other organization").

26. H. Lauterpacht, Recognition of States in International Law, 53 YALE L. J. 385, 410 (19431944) ("The second essential requirement of statehood is a sufficient degree of internal stability as expressed through the functioning of a government enjoying the habitual obedience of the bulk of the population").

27. Benedict Anderson, Imagined Communities: Reflections of the Origin and SPREAD OF NATIONALISM (1991). 
The significance of effectiveness as the signature element of statehood is readily apparent in the words and deeds of the statesmen, jurists and legal scholars of the late nineteenth and early twentieth century. During the nineteenth century, governments contemplating the recognition of aspirant entities emphasized effectiveness as a crucial empirical prerequisite for statehood. ${ }^{28}$ In determining whether newly independent Mexico qualified as a state, British Foreign Secretary Canning focused upon two aspects of effectiveness. First, he questioned whether the Mexican government was "in military possession of the country, and also whether it was in a respectable condition of military defense against any probable attack from Europe" (e.g., territorial control). Second, he questioned whether the Mexican government had "acquired a reasonable degree of consistency" and enjoyed "the confidence and goodwill of the several orders of the people" (e.g., control over people). ${ }^{29}$ US President Grant also emphasized control over the population as a prerequisite to statehood when he refused to recognize Cuba's independence until there was "some known and defined form of government, acknowledged by those subject thereto, in which the functions of government are administered by usual methods, competent to mete out justice to citizens and strangers, to afford remedies for public and for private wrongs, and able to assume the correlative international obligations and capable of performing the corresponding international duties resulting from its acquisition of the rights of sovereignty." 30

Pre-UN international organizations also explicitly and implicitly understood statehood in terms of effectiveness. In assessing whether a mandatory territory qualified as a state, the League of Nations identified the following criteria in 1931: 1) a settled government and an administration capable of maintaining the regular operation of essential government services, 2) capacity to maintain its territorial integrity and political independence, 3) capacity to maintain peace throughout the territory. ${ }^{31}$ Article 1 of the Montevideo Convention of 1933 provides the standard requirements for statehood and personality in international law: "a) a permanent population, b) a defined territory, c) government, and d) capacity to enter into relations with other states." 32

28. Although this Article focuses on the existence of states as subjects of international law, rather than the recognition of new states, the recognition of a new state presupposes that a new state exists. Thus, changes in the recognition of states reflect changes in the understanding of statehood.

29. Canning's dispatch of October 10, 1823, in 1 BRITAIN AND THE INDEPENDENCE OF LATINAMERICA, 1812-1830, 435 (Webster ed. 1938).

30. 1 J.B. MOORE, Digest OF INTERNATIONAL LAW 107-108 (1906). (1931).

31. Report of the Permanent Mandates Commission, 12 League of Nations O. J. 2176

32. Convention on Rights and Duties of States, Dec. 26, 1933, 165 L.N.T.S. 19; see also RESTATEMENT (THIRD) OF FOREIGN RELATIONS LAW OF THE UNITED STATES § 201 (1987) (defining a state as "an entity that has a defined territory and a permanent population, under the control of its own government, and that engages in, or has the capacity to engage in, formal relations with other such entities"); CRAWFORD, supra note 23, at 36 ("It is a characteristic of these criteria . . that they are based on the effectiveness among territorial units"). 
Jurists of the early twentieth century considered effectiveness the sine qua non of statehood as well. Following Finland's independence from Russia in 1917, a Commission of Jurists appointed by the League of Nations observed that Finland did not achieve statehood immediately upon independence:

$[F]$ or a considerable time, the conditions required for the formation of a sovereign State did not exist. In the midst of revolution and anarchy, certain elements essential to the existence of a State, even some elements of fact, were lacking for a fairly considerable period. Political and social life was disorganized; the authorities were not strong enough to assert themselves ... the Government has been chased from the capital and forcibly prevented from carrying out its duties . . . It is therefore difficult to say at what exact date the Finnish Republic, in the legal sense of the term, actually became a definitely constituted sovereign State. This certainly did not take place until a stable political organization had been created, and until the public authorities had become strong enough to assert themselves throughout the territories of the State without the assistance of foreign troops. ${ }^{33}$

Leading treatises of international law from the nineteenth and early twentieth century enumerate similar criteria. Phillimore defines a state as "a people permanently occupying a fixed territory, bound together by common laws, habits and customs in one body politic, exercising, through the medium of an organized Government, independent sovereignty and control over all persons and things within its boundaries." 34 According to Wheaton, the "legal idea of a State necessarily implies that of the habitual obedience of its members to those persons in whom the superiority is vested." 35 Lauterpacht states that "the requirements of statehood as laid down by international law and as uniformly expressed in text-books, [are] namely, the existence of an independent government exercising effective authority within a defined area."36 According to Lawrence, a state is "political community, the members of which are bound together by the ties of a common subjection to some central authority, whose commands the bulk of them habitually obey." 37 Noting that the "sovereign state is the typical subject of international law," 38 Schwarzenberger states that "it has become customary to assume that a subject of international law must have a stable government, which does not recognize any outside superior authority, [and] that it must rule supreme within a territory." 39

33. Aaland Island Dispute, LeAGUe of NATIONS O. J., Special Supplement, No. 4, 8-9 (1920) (emphasis added).

34. 1 Robert Phillimore, COMmentaries Upon International LaW 94 (1854) (emphasis added).

35. HENRY WhEATON, ELEMENTS OF INTERNATIONAL LAW $26\left(8^{\text {th }}\right.$ ed. 1866).

36. Lauterpacht, supra note 26, at 408.

37. T.J. LaWrence, The Principles of International LaW 48 ( $7^{\text {th }}$ ed. 1928) (emphasis added).

38. SCHWARZENBERGER, supra note 3, at 122 (lists the essential characteristics of the state as "an organized government, a defined territory, and such a degree of independence of control by any other state as to be capable of conducting its own international relations").

39. Id. at 31 (emphasis added); See also HANS Kelsen, PrinCIPLES OF InTERNATIONAL LAW 100-102, 108 (1952) (describing the state as a centralized coercive legal order possessing a monopo- 
Two additional points should be noted about the role of effectiveness in statehood. First, the temporary loss of effective control due to insurgency or belligerent occupation did not necessarily compromise statehood in the eyes of other governments. As Part III illustrates, temporary lapses of control were common and other governments tolerated these lapses. However, chronic ineffectiveness was a different matter. When effective control was the exception rather than the rule within a territory the existence of a state could not be taken for granted. Second, though statesmen may have promoted policy aims by conditioning the recognition of states upon additional normative considerations, such as the slave trade, religion, the degree of civilization, or the existence of a democratic government, these criteria were supplements to-not substitutes for-the factual prerequisite of effective control.

In sum, from the standpoint of international law, the key criteria of effective, factual statehood were not the existence of an impersonal technocratic bureaucracy, the character of the state's legal order, or other components of Max Weber's classic formulation per se. Rather, the most important criteria were the control over violence within a defined territory. ${ }^{40}$ These other features are relevant only to the extent that they enable a state to exercise effective control over people and territory. As summarized by Fukiyama, "[t]he essence of stateness is, in other words, enforcement: the ultimate ability to send someone with a uniform and a gun to force people to comply with the state's laws." 41

\section{B. Sovereignty: Positive vs. Negative}

The sine qua non of traditional effective statehood in international law is effective control or positive sovereignty. ${ }^{42}$ An entity's positive sovereignty is a function of the "capabilities which enable governments to be their own masters: it is a substantive rather than a formal condition." 43 Secretary of State Lansing considered such positive sovereignty, to have the following attributes.

1) Sovereignty is real (or actual) only when the possessor can compel the obedi-

ly on force).

40. Max Weber, The Theory of Social and Economic Organization 156 (A.M. Henderson \& Talcott Parsons trans., Talcott Parsons ed., 1947).

41. Francis Fukiyama, State-Building: Governance and World ORder IN THE $21^{\mathrm{sT}}$ CENTURY 6 (2004).

42. See JACKSON, supra note 3, at 29 (describing the related concept of empirical statehood). I employ the term effective state to emphasize the key attribute of statehood, effective control of people and territory.

43. JaCKSON, supra note 3, at 29; TheOdORE DWight WoOlSEY, INTERNATIONAL LAW 35 $\left(6^{\text {th }}\right.$ ed., 1897) ("By sovereignty we intend the uncontrolled exclusive exercise of powers of the state; that is . . the power of governing its own subjects"); see also STEPHEN D. KRASNER, SOVEREIGNTY: ORGANIZED HYPOCRISY (1999) 3-4 (distinguishing between different forms of sovereignty); CRAWFORD, supra note 23, at 42 (Explaining that traditionally "international law defines 'territory' not by adopting private law analogies of real property, but by reference to the extent of governmental power exercised, or capable of being exercised, with respect to some area and population. Territorial sovereignty is not ownership of, but governing power with respect to, territory"). 
ence to the sovereign will of every individual composing the political state and within the territorial state.

2) Such complete power to compel obedience necessarily arises from the possession of physical force superior to any other such force in the state.

3)The exercise of sovereignty in a state does not involve reasonableness, justice or morality, but is simply the application or the menace of brute force. ${ }^{44}$

Positive sovereignty is a political fact. It exists in contradistinction to negative sovereignty, which is a legal right to non-intervention and non-interference. ${ }^{45}$

The state-centric security paradigm embodied in the UN Charter came into existence at a time when normative principles such as non-intervention flowed from factual precedents. "Independence and territorial as well as personal supremacy are not rights, but recognized and therefore protected qualities of states as International Persons." 46 Negative sovereignty is the "[r]espect for the inviolability of the territory of a State and rests on the theory that it possess the power and will to exercise control therein." 47 Thus the internal might of positive sovereignty entitled one set of governing elites to the external right of nonintervention vis-à-vis external governing elites.

\section{The One Army Rule of Statehood}

From the traditional indicia of sovereign statehood I derive what I term the "one army rule" of sovereign statehood. ${ }^{48}$ A single, supreme military force within a defined territory characterizes a sovereign state. ${ }^{49}$ A state cannot enjoy a monopoly on force if there is another, independent armed force within its territory. If a state voluntarily or involuntarily shares its territory with an independent armed group, its positive sovereignty is compromised.

The logic of the UN Charter's use of force regime is contingent upon the one-army rule. A state-centric regime is tenable only as long as the putative state authorities exercise effective control over their nominal territory and any military forces within this territory. A state-centric framework is viable if governments can bind all the significant armed groups in a regime of non-aggression and non-intervention vis-à-vis other states. Violation of the one-army rule not only compromises an entity's sovereignty, but also undermines a state-centric

44. Robert Lansing, Notes on Sovereignty in a State, 1 AM. J. INT'L L. 105, 110 (1907) (emphasis added).

45. JACKSON, supra note 3, at 1,50-53.

46. OPPENHEIM, INTERNATIONAL LAW 234 (Hersch Lauterpacht ed., 5th ed. 1935).

47. 1 Charles Cheney Hyde, International LaW, 646 (1945).

48. See W. Michael Reisman, Private Armies in a Global War System, in LAW AND CIVIL WAR IN THE MODERN WORLD 252, 256-69 (John Norton Moore ed., 1974). Professor Reisman discusses the related concept of the "private army rule," that is, the traditional intolerance by the international community for private armed groups and the strict attribution of their violence to their territorial host. I use of the term "one army rule" to highlight the implications for sovereignty and the ideal of statehood posed by the presence of non-state armed groups.

49. This is a necessary but not sufficient condition for statehood. 
security regime.

As described in the next Part, the ideal of sovereign statehood is rarely realized and the one army rule is often violated in practice. This gap between the ideal and reality of statehood is a longstanding and persistent fact. Rather than a world divided between contiguous states, each containing a single armed force, we have long lived in a world of states, fictitious states and violent non-state actors. In this world, the internationally recognized territorial ruler is often not the ruler of the territory.

II.

\section{A Growing Problem: Fictitious Statehood}

Taken by itself, a state-centric security regime is inadequate to regulate the use of force and preserve minimal public order because the two assumptions upon which the regime is premised are invalid. First, weak states are the norm rather than the exception in much of the world. ${ }^{50}$ Second, violent non-state actors possess significant military capabilities often comparable to those of state militaries and thus pose internationally significant security threats. The large number of conflicts involving weak states and transnational non-state actors alone demonstrates the inadequacy of the state-centric regime. ${ }^{51}$

This Part explains how and why the predicate conditions for an exclusively state-centric security regime have never existed, and why state-centrism became even less tenable in the wake of decolonization. I then use the case study of the Democratic Republic of the Congo (DRC) to illustrate both the security threat resulting from the absence of effective central authority and the response of one major international body, the International Court of Justice, to the problem of fictitious statehood.

\section{A. Effective Statehood is the Exception}

From a global perspective, states exercising effective control over their territory and the people within that territory are anomalous. This fact, long appreciated by social scientists, is often neglected by legal scholars and policymakers. ${ }^{52}$

50. See JACKSON, supra note 3; HERBST, supra note 4; Clapham, supra note 4; CENTENO, supra note 4.

51. James D. Fearon \& David D. Laitin, Ethnicity, Insurgency and Civil War, 97 AMER. POL. SCI. REV. 75 (2003).

52. See, e.g., David Nugent, Building the State and Making the Nation: The Bases and Limits of State Centralization in Modern Peru, 96 AM. ANTHRopologisT 333, 335 (1994) (reviewing the social science literature discussing differences between contemporary Western and non-Western states); Thomas Blom Hansen \& Finn Stepputat, Introduction, in States of IMAGinAtion: EthNOGRAPHiC ExPloRation of the PostColonial STATE 2 (Thomas Blom Hansen \& Finn Stepputat, eds., 2001) (noting that the "myth of the state seems to persist in the face of everyday experiences of the often profoundly violent and ineffective practices of government or outright collapse of states. It persists because the state, or institutional sovereign government, remains pivotal in 
Although there is awareness among policymakers of the problem that "failed states" pose, the term "failed state" itself presupposes the prior existence of a state. It thus reflects a fundamental misunderstanding of the realities of political power around the globe. ${ }^{53}$ For the most part, the regions beyond the writ of any central government are not states that failed. They are instead regions where effective states never existed.

This is not to say that states do not exist outside of Europe and its settlement colonies. Rather, where states exist, they often do not exercise effective control over the territory within their borders. As in Afghanistan, the governments of many countries have employed the "Swiss cheese approach" to governance. ${ }^{54}$ The state controls only the most populated and economically valuable areas and leaves autonomous the populations of the economically/environmentally marginal and difficult to control regions, such as mountains and deserts, so long as they do not challenge the central authorities. ${ }^{55}$ Put differently, the writ of the state is not congruent with the international borders of the country it occupies. Sometimes the states within such territories are little more than city-states.

Examples of such fictitious states abound. "Many other regions of the world share the African experience of having significant outlying territories that are difficult for the state to control because of relatively low population densities and difficult physical geographies." ${ }^{56}$ In Latin America,

The state's capacity to maintain monopoly over the use of violence or territoriality has also always been suspect. With a couple of exceptions, few national capitals could be said to have ruled the hinterlands of the nineteenth or even early twentieth century. Even today, Peru, Ecuador, and Bolivia still lack the ability to control the Sierra; Mexico continues to fight rebels in at least two provinces; Brazil cannot enforce federal policies on regions; and Colombia is quickly disintegrating. 57

Fictitious states span a broad range of capabilities. ${ }^{58}$ Fictitious states in-

our very imagination of what a society is"); JAMES C. SCOTT, THE ART OF NOT BEING GOVERNED: AN ANARCHIST HISTORY OF UPLAND SOUTHEAST ASIA 3-4 (2010); see generally JACKSON, supra note 3; HerBST, supra note 4; Clapham, supra note 4; CENTENO, supra note 4.

53. For examples of this misunderstanding, see National Security Strategy, supra note 10, at 1 ("America is now threatened less by conquering states than we are by failing ones"); Yoo, supra note 8; Dunlap, supra note 8; The Failed State Index 2009, available at http://www.foreignpolicy.com/articles/2009/06/22/2009_failed_states_index_interactive_map_and_r ankings [hereinafter The Failed State Index 2009].

54. Thomas Barfield, Afghanistan: A Cultural And Political History 67-70 (2010) (contrasting the "American cheese" approach of homogenous control within international borders with the "Swiss cheese" approach on internally heterogeneous control).

55. Id.

56. HERBST, supra note 4.

57. Centeno, supra note 4 at 6 . Although written in 2002, Centeno's general observations regarding state weakness remain accurate despite the fact that state control has deteriorated further in Mexico and improved in Colombia.

58. For indices of some of the territorial entities I term fictitious states, see Int'l Dev. Ass'n, 
clude entities such as Somalia, which lack any central authority. However, even territorial entities such as India ${ }^{59}$ that contain strong states are fictitious to the extent that their borders are not coterminous with the writ of their central governments. The extent of an entity's statehood is fictitious to some degree whenever the central government is unwilling or unable to establish control over some portion of its territory.

A state may possess formidable military capabilities yet be unable to exercise effective control over its own territory. In Sudan, the al-Bashir government in Khartoum is capable of committing atrocities in Darfur but incapable of compelling compliance with its commands throughout much of Sudanese territory. ${ }^{60}$ The quintessential example is Pakistan, which possesses a nuclear arsenal but cannot control its Federally Administered Tribal Areas. ${ }^{61}$ The ability of territorial elites to destroy is not the ability to control. The central authorities of fictitious states may be dangerous internally and externally, yet they may still be ineffective. Prior to the twentieth century even the United States faced difficulty in suppressing violent non-state incursions from its territory into Canada, Mexico, and Central America. ${ }^{62}$

The effective state is neither the default form of government nor a natural function of territory. They are a form of political organization and therefore aspects of human culture. The state is a set of relationships and understandings relating to authority, compliance, loyalty, and identity.

The political relationships characterizing the state are historically contingent. ${ }^{63}$ There is no reason to assume that the complex historical processes lead-

Operational Policy and Country Servs. and Res. Mobilization Dep't, Operational Approaches and Financing in Fragile States, at 2 (June 2007); SUSAN E. RICE \& STEWART PATRICK, BROOKINGS Institution Index of State Weakness In the Developing World (2008); The Failed State Index 2009, supra note 53.

59. Not a Dinner Party, The ECONOMIST, Feb. 27, 2010, at 46, 48 (describing the 40-year-old Maoist Naxalite insurgency in India, which claims "to be fighting for better treatment of marginalized tribes, but deny the government access to areas they control"); Politics with Bloodshed, THE ECONOMIST, Apr. 10, 2010, at 45 (describing the Naxalites as having had "an estimated 14,000 fulltime fighters and loose[] control of a swathe of central and eastern India, albeit in jungle areas where the state is hardly present").

60. The Failed State Index 2009, supra note 53 (ranking Sudan as the third most "failed" state).

61. Iftikhar A. Khan, Taliban's Bajaur Base Falls, Army Eyes Tirah, Orakzai, The Dawn, Mar. 3, 2010, available at http:/www.dawn.com/wps/wcm/connect/dawn-contentlibrary/dawn/news/pakistan/04-army-bajaur-qs-10 ("Maj-Gen Tariq said the Pakistan flag had been raised in the region for the first time since independence").

62. Roy Emerson Curtis, The Law of Hostile Military Expeditions as Applied by the United States, 8 AM. J. INT'L L. 224 (1914) (describing the United States' often ineffective response to "filibusters" and other violent non-state actors based on American soil).

63. See Hansen \& Stepputat, supra note 52, at 7 (noting the historical contingency of "features, functions and forms of governance" characterizing the state); CHARLES TILly, COERCION, CAPITAL, AND EUROPEAN STATES, AD 990-1992 (1992); JACKSON, supra note 3, at 7 ("Far from being natural entities, modern sovereign states are entirely historical artifacts the oldest of which have been in existence in their present shape and alignment only for the past three or four centuries. 
ing to the formation of the effective state, as understood by Charter-era international law, played out the same everywhere in the world. Extensive scholarship in the social sciences indicates that the environmental ${ }^{64}$ and demographic factors ${ }^{65}$ as well as the resulting prehistoric and historic processes ${ }^{66}$ leading to the in situ development of effective states in parts of Eurasia did not occur in all regions of the world, particularly Latin America and Africa. ${ }^{67}$ The development of the effective state was far from universal. Moreover, future development towards the Euro-centric model of effective statehood is unlikely. ${ }^{68}$ The differing conditions and developmental trajectories of different areas of the world result in different forms of political organization, not all of which can be characterized as effective states.

To summarize, many of the territorial communities recognized as states are legal fictions to some degree. Effective states exercising direct, relatively homogenous effective control throughout their internationally-recognized borders are anomalous in much of the world. The next section traces how the primarily European phenomenon of effective statehood came to be universalized into a principle of justice.

\section{B. Statehood as Norm, Not Fact: Reification of Fictitious Statehood}

The reality of statehood is not universal. However, the ideal of-indeed the right to - statehood gained widespread acceptance in the mid-twentieth century. This Section examines the transformation of statehood from an empirical fact into a principle of justice.

\section{The Delegitimization of Formal Political Inequality}

The principles of self-determination and human equality gained ascendance following the Second World War. ${ }^{69}$ Western statesmen generalized liberalism

Prior to that time human populations in Europe where the modern state was invented and elsewhere organized themselves politically along rather different institutional lines . . " ).

64. See JARED DiAmOND, GunS, GERMS AND STEEL (1997); BARFIELD, supra note 54; AfGHanistan: A Cultural AND Political History 67-70 (2010); SCOTT, supra note 52.

65. Id.

66. TiLly, supra note 63 (describing the factors that led to the development of the "national state", analogous to the effective state, in Europe but not in other regions of the world).

67. CENTENO, supra note 4; HERBST, supra note 4.

68. Clifford Geertz, What is a State If It is Not a Sovereign: Reflections of the Politics of Complicated Places, 45 CURRENT ANTHROPOLOGY 577, 578 (2004) ("[S]o far as state formation . . . is concerned, whatever has already happened in supposedly better-organized places is less prologue than chapters in a different sort of story not to be reenacted. Whatever directions what is called . . . "nation building" may take in Africa, the Middle East, Asia, or Latin America, a mere retracing without the bloodshed of earlier cases-England, France, or Germany, Russia, the United States, or Japan - is not in the cards ...").

69. JACKSON, supra note 3, at 16 (“[D]omestic ideologies promoting enfranchisement of racial and ethnic minorities in Western states” reinforced such international equality norms.) 
among individuals to liberalism among societies. ${ }^{70}$ If all peoples are equal, then they must all have the same capabilities with respect to political organization.

\section{Decolonization}

The transformation of statehood and sovereignty from empirical realities into international norms was largely a product of decolonization. Major powers recognized that colonial peoples were entitled to statehood as a right. ${ }^{71}$ The international community adhered to and enforced principles of "equal rights and self determination of peoples," 72 as well as territorial integrity ${ }^{73}$, uti possidetis, and non-intervention. The result of decolonization was the creation of entities with international legal personalities irrespective of their internal capabilities.

During decolonization, indigenous elites, particularly those educated in the metropolis, embraced the ideal of European-style statehood because it was "modern," 74 and also because it was the only means by which they could enjoy formal equality vis-à-vis European elites. If states were the principal entities of the world community, then indigenous elites needed states to stand on equal footing with European colonial powers. Through the process of decolonization, the European Westphalian state system became globalized.

However, most of these soon-to-be independent colonial entities had never been states prior to colonization, or at least not states defined by their external colonial frontiers. European colonial rule did not usually result in the formation of effective states either. The exogenous creation of effective states, even if possible, had not been the program of most European colonial powers. ${ }^{75}$ Yet, during decolonization many governments apparently "assumed that the new, young countries would ultimately develop into carbon copies of the European and North American states." 76 This assumption has proven to be generally unfounded. ${ }^{77}$ Herbst's observation relating to Africa is germane to many other areas of the world, particularly the Middle East and South and Central Asia, from which

70. Id. at 14 ("The constitutional leveling that occurred within Western domestic societies has taken place internationally and for most of the same reasons which have to do with the doctrine of equal rights and equal dignity of all mankind").

71. Id.

72. U.N. Charter art. 1, para 1.

73. Id. at art. 2, para 4.

74. HERBST, supra note 4, at 99-101.

75. See generally, Crawford Young, The African Colonial State in CONTEMPORARY PERSPECTIVE (1994).

76. K.J. Holsti, The State, War, And the State of War 101 (1996).

77. Id. at 79 ("The universalization of the territorial state format does not mean that all states share the same characteristics. In particular, artificial states - the creation of colonial authorities and international organizations - are in many ways fundamentally different from states that grew slowly through organic processes involving wars, administrative centralization, the provision of welfare environments, and the development of national identities and sentiments"). 
many contemporary threats emanate. ${ }^{78}$ "[I]nternational society, by dint of the granting of sovereignty, still assumes that all African countries are able to control all of the territory within their boundaries. The gap between how power is exercised in Africa and international assumptions is significant and, in some cases, growing." 79

In the societies traditionally characterized by effective states, statehood and positive sovereignty were taken for granted. Many Western policymakers have blithely assumed that if all peoples are equal, then that equality must be on Western terms. ${ }^{80}$ In addition, the governments of European colonial empires tired of their colonial projects in the face of rising costs, growing condemnation at home and abroad, and, in some cases, successful indigenous rebellions. Finally, the leaders of the major Communist powers (and to a lesser extent the United States) sought Cold War advantage in backing independence and statehood ambitions of Europe's overseas colonies.

Thus, the leaders of post-colonial entities became entitled to negative sovereignty, even when they could not demonstrate positive sovereignty. Like statehood more generally, sovereignty has been transformed from a fact into a norm. Traditionally, the non-intervention norm of negative sovereignty flowed from the empirical reality of positive sovereignty (e.g., ultimate control over some delimited territory). From the mid-twentieth century, negative sovereignty became a right of all states, irrespective of their capabilities to exercise effective control over their territory. This normative shift redefined statehood.

\section{1960 and the Redefinition of Statehood}

The year 1960 stands as the watershed year for the acceptance of fictitious statehood in international law. Many governments and international institutions unequivocally rejected the traditional criteria for statehood in words and deeds. The United Nations' Declaration on the Granting of Independence to Colonial Countries and Peoples ("Declaration") proclaimed that "[a]ll peoples have the right to self-determination; by virtue of that right they freely determine their political status and freely pursue their economic, social and cultural development." ${ }^{\text {"1 }}$ The General Assembly rejected effectiveness as a precondition for statehood: "Inadequacy of political, economic, social or educational preparedness should never serve as a pretext for delaying independence." 82 The Declaration called on all states to observe its provisions "on the basis of equality, noninterference in the internal affairs of all States, and respect for the sovereign

\footnotetext{
78. See generally RABASA, supra note 13 .

79. HERBST, supra note 4, at 3.

80. JACKSON, supra note 3, at 15-17.

81. G.A. Res. 1514 (XV), ๆ 3, U.N. Doc. A/64 (Dec. 14, 1960).

82. Id. $\llbracket 2$ (original emphasis).
} 
rights of all peoples and their territorial integrity." 83 Irrespective of their capabilities, colonial peoples were now entitled to independent statehood and the right to negative sovereignty that accompanied it. The central authorities of these post-colonial entities were entitled to exclude others from their nominal territory regardless of whether they themselves exercised effective control over it.

As the archetypal fictitious state, the status of the DRC in international law illustrates the changed understanding of statehood, as well as the ramifications of this redefinition for global security. In 1960, the same year as the Declaration, the DRC became a member of the United Nations. Yet following Belgium's withdrawal as the colonial power, the DRC had descended into anarchy. ${ }^{84}$ The DRC lacked any semblance of a government exercising control over the area or population of its nominal territory. Thus, the DRC failed the crucial traditional test for statehood under international law. ${ }^{85}$ Notwithstanding the ostensible limitation of UN membership to states ${ }^{86}$, the United Nations admitted the geographical expression of the DRC without dissent. ${ }^{87}$

Despite the absence of a government exercising anything approaching effective control, there was and continues to be a formal commitment by the international community to the sanctity of the DRC's territorial integrity and negative sovereignty. Thus, the UN Security Council condemned as illegal the attempted secession of the DRC's Katanga province. ${ }^{88} \mathrm{UN}$ forces intervened on behalf of the authorities in Kinshasa and were instrumental in suppressing Katanga's attempted independence. A slew of Security Council resolutions have reaffirmed the commitment of its member governments "to the sovereignty, territorial integrity and political independence of the Democratic Republic of the Congo" 89 and even expressed an unfounded expectation that the "Government of the Democratic Republic of the Congo [is capable of] ensuring security in its territory and protecting its civilians with respect for the rule of law, human rights and international humanitarian law." 90 The International Court of Jus-

83. Id. ๆ7.

84. CRAWFORD, supra note 24, at 42-44 ("Anything less like effective government it would be hard to imagine").

85. Id. at 43-44 (noting that the DRC's admission to the United Nations signaled a relaxation of the criteria of effective government).

86. U.N. Charter art. 4, para. 1 ("Membership in the United Nations is open to all other peaceloving states which accept the obligations contained in the present Charter and, in the judgment of the Organization, are able and willing to carry out these obligations").

87. S.C. Res. 142, U.N. Doc. S/RES/4377 (July 7, 1960); G.A. Res. 1480 (XV), U.N. Doc. A/4684 (Sept. 20, 1960).

88. S.C. Res. 169, U.N. Doc. S/RES/169 (Nov. 24, 1961).

89. S.C. Res. 1807, U.N. Doc. S/RES/1807 (Mar. 31, 2008); S.C. Res. 1856, U.N. Doc. S/RES/1856 (Dec. 22, 2008); S.C. Res. 1804, U.N. Doc. S/RES/1804 (Mar. 13, 2008); S.C. Res. 1439, U.N. Doc. S/RES/1439 (June 26, 2003); S.C. Res. 1751, U.N. Doc. S/RES/1751 (Apr. 13, 2007).

90. S.C. Res. 1807, U.N. Doc. S/RES/1807 (Mar. 31, 2008); S.C. Res. 1856, U.N. Doc. S/RES/1856 (Dec. 22, 2008). 
tice's Armed Activities on the Territory of the Congo (Dem. Rep. Congo v. Uganda), 2005 I.C.J. 168 (Dec. 19), discussed in Section D, clearly illustrates the disconnect between the formal commitment to the fiction of Congolese sovereignty and state practice.

The themes of decolonization, the normative quality of statehood, and the equation of independence with statehood, remain relevant today. For example, the question of whether Palestinians deserved statehood was a persistent theme during the recent debate over the recognition of Palestinian statehood at the United Nations. ${ }^{91}$ The equation of territorial independence with statehood is evident in the recent admission of South Sudan into the United Nations as a member state. ${ }^{92}$ This recognition followed close on the heels of South Sudan's declaration of independence from the north, despite the extremely rudimentary character of the South's central institutions. ${ }^{93}$

\section{Suspending Disbelief in Fictitious States}

As the DRC's persistence reveals, once born, the fictitious states of the post-colonial era retain their international legal personality irrespective of their actual internal capabilities. Governments have been loath to fully and expressly acknowledge the gulf between the theory and reality of statehood in much of the world. Such acknowledgement would have resulted in the "derecognition" of completely fictitious states such as the DRC and Somalia. ${ }^{94}$ Major powers continue to commit to the existence of fictitious states for a number reasons. ${ }^{95}$ Foremost among them is a "domino theory" of derecognition. For example, the derecogition of a completely fictitious state such as Somalia might destabilize other marginal entities such as Chad. ${ }^{96}$ Second, the international community simply does not know what to do with stateless territories. ${ }^{97}$ A lack of imagina-

91. Helene Cooper, Obama Says Palestinians Are Using Wrong Forum, N.Y. Times, Sept. 21, 2011, available at https:/www.nytimes.com/2011/09/22/world/obama-united-nations-speech.html (conceding that the "Palestinian people deserve a state of their own").

92. See The UN Welcomes South Sudan as $193^{\text {rd }}$ Member State, The United NATIONS, (Jul. 14 , 2011), available

http://www.un.org/apps/news/story.asp?NewsID $=39034 \& C r=S o u t h+S u d a n \& C r 1=$.

93. See Now the Hard Part, The ECONOMIST, Feb., 3, 2011 (describing the weakness of South Sudan's central government vis-à-vis tribal chiefs); International Crisis Group, Politics and Transition in the New South Sudan, 18 (Apr. 4, 2011) (describing "minimal" delivery of security at both the state and county level), available at http://www.crisisgroup.org/ /media/Files/africa/horn-ofafrica/sudan/172\%20-

\%20Politics\%20and\%20Transition\%20in\%20the\%20New\%20South\%20Sudan.pdf.

94. See Jeffery Herbst, Let them Fail: State Failure in Theory and Practice, in WHEN STATES FAIL: CAUSES AND CONSEQUENCES 301-16 (Robert I. Rotberg ed., 2004) (exploring the possibility of "decertifying" the existence of failed states and as well as recognizing new states).

95. Robert J. Delahunty \& John Yoo, Statehood and the Third Geneva Convention, 46 VA. J. INT'L L. 131, 149-153 (2005).

96. Id. at $149-150$.

97. $I d$. 
tion, resources, interest, and long-term commitment all militate against exploring alternative forms of political organization such as protectorates or trusteeships. ${ }^{98}$ Third, the abolition of a territory's de jure statehood, and hence claims to negative sovereignty, leaves such territories vulnerable to predatory interventions and territorial competition by other states. ${ }^{99}$ The current international system exists in large measure to prevent such wars of territorial conquest. ${ }^{100}$ Fourth, derecognition would render the territory's population stateless and thus deprive it of both status and protection under international law. ${ }^{101}$ Thus, governments have significant reasons to maintain the current statehood charade and to continue suspending disbelief. Despite these policy considerations speaking against derecognition, the ubiquity of fictitious states and the rarity of effective statehood has serious implications for a global security regime premised upon a system of states. The UN Charter's state-centric use of force regime is predicated upon states exercising a monopoly over force within their territorial boundaries.

However, because weak states are unable to control their populations and territories, weak states cannot be relied upon to fulfill their international obligations. Samuel Huntington's observation that "[t]he most important political distinction among countries concerns not their form of government, but their degree of government" is particularly germane to international security and the regime governing the use of force. ${ }^{102}$ Whereas in the nineteenth and early twentieth century the gaps between the theory and fact of statehood were generally exceptions, after the mid-twentieth century the existence of such gaps between legal identity and political reality became the norm throughout much of the world. Because decolonization transformed the mismatch between the ideal and reality of statehood from a marginal and usually temporary condition into a permanent state of affairs, it exacerbated the challenges posed by fictitious statehood.

The gap between the ideal of effective statehood and the reality of fictitious statehood provides a habitat for violent non-state actors to thrive. ${ }^{103}$ The next section briefly examines some of the characteristics of the non-state entities, which occupy the lacuna between the fact and fiction of statehood and threaten international order.

98. Id.

99. Id.

100. Frontier Dispute (Burk. Faso v. Mali), 1986 I.C.J. 554, 920 (Dec. 22) (noting that the purpose of uti possidetis in the context of decolonization of Spanish America and Africa was "to prevent the independence and stability of new States being endangered by fratricidal struggles provoked by the challenging of frontiers").

101. Delahunty \& Yoo, supra note 95 , at 149-150.

102. Samuel Huntington, Political ORder in Changing Societies 1 (1968) (emphasis added).

103. See RABASA, supra note 13 (a RAND Corporation analysis for the United States Air Force of the security threats present in several ungoverned areas). 


\section{Violent Non-State Actors}

Under a variety of labels - terrorists, marauders, mafias, filibusters, pirates, armed bands, warlords, militias, mercenaries, private armies, insurgents, bandits, free-companies, narco-trafficantes, and the militaries of de facto states - violent non-state actors have been a longstanding fact of international relations. ${ }^{104}$ Indeed, not only have they continuously existed alongside modern sovereign states, they precede the modern state. The persistence of independent non-state actors is the corollary to the anomalous nature of effective statehood. Groups such as Hizbollah and the Somali pirates serve as reminders that the ideal of statehood is often unrealized in reality. ${ }^{105}$ When such non-state actors exercise independent decision-making and control of their members, their existence violates the "one army rule" of sovereign statehood. Yet, the major powers downplayed or outright ignored the significance and strength of independent non-state actors during decolonization. ${ }^{106}$ The international legal regime that developed to support fictitious states could not formally accommodate the existence of violent non-state actors. Explicit acknowledgment would have exposed the gulf between the reality and ideal of statehood in many of the world community's newest members.

This Article focuses on independent violent non-state actors. Such actors neither satisfy the ICJ's "effective control" test for state responsibility, ${ }^{107}$ nor do they function as de facto agents of state authorities. Although these independent actors may receive safe-harbor, and financial and logistical support from states, the relationships between states and non-state actors are alliances, not forms of agency. The relation of independent non-state actors to state authorities is horizontal, not vertical.

The fact that the internal organizational structure of these non-state actors varies, ranging from a quasi-military hierarchy to a diffuse network of cells or individuals, is irrelevant for the legal framework governing the recourse to force. Although organizational structure may be relevant to the applicability of some provisions of the law of armed conflict (jus in bello $)^{108}$, it is irrelevant to

104. For typologies and indices of violent non-state actors of international consequence, see The International Institute for Strategic Studies, The Military Balance 465-474 (2009); GRegor Wettberg, International Legality of Self-Defense Against Non-State ACTORS 48-60 (2007); Ulrich Schneckener, Fragile Statehood, Armed Non-State Actors and Security Governance, in PRIVATE ACTORS AND SECURITY GOVERNANCE, 23-25 (Alan Bryden \& Marina Caparini eds., 2006).

105. Fearon \& Laitin, supra note 51, at 88 (finding that state weakness permitting the development of insurgency is a strong predictor of civil war).

106. Reisman, Private Armies in a Global War System, supra note 48, at 258 (noting that "the traditional private-army rule seems to have been explicitly rejected by Communist states in association with a number of nations in the Third World"), at 259 ("If the private-army rule of international law were strictly applied and reprisals were undertaken, these nominal states might crumble").

107. Military and Paramilitary Activities (Nicar. v. U.S.), 1986 I.C.J. 14, \ 115 (June 27).

108. Geneva Convention (III) Relative to the Treatment of Prisoners of War, art. 4(2), Aug. 12, 
the rules with respect to recourse to force (jus ad bellum). The only relevant factors for jus ad bellum are: 1) that the non-state actor operates across an international frontier, and 2) the magnitude of the security threat posed by the non-state actor. ${ }^{109}$ Non-state actors lacking the traditional military-style command structures may nonetheless pose serious threats to international security.

Although areas such as Somaliland, Kurdistan, Hamas-controlled Gaza, or Hezbollah-occupied southern Lebanon host non-state actors that may function as de facto states, many significant violent non-state actors organize themselves according to principles that are radically different from sovereign statehood. Such actors include those whom the classical Islamic political thinker Muhammad Ibn Khaldu's called the "desert peoples," i.e., tribal societies occupying environmentally marginal regions and resisting control by central authorities. ${ }^{110}$ Although predatory armed groups are less immediately relevant to American security than $\mathrm{Al}$ Qa'ida, these groups pose a greater threat to overall human security, particularly in central Africa. Militias such as the Mai Mai, the Forces Démocratiques pour la Libération du Rwanda and the Congrès National pour la Defénse du Peuple are among the rotating cast of dozens of independent armed groups that kill, rape and pillage in the DRC and neighboring countries. The threat posed by such groups is emphasized by the recent dispatch of US Special Forces to aid Ugandan efforts against the Lord's Resistance Army. ${ }^{111}$ These groups have played key roles in a complex series of interconnected regional armed conflicts in central Africa that have killed millions, all the while paying little heed to such niceties as international borders.

Independent violent non-state actors are the complement to the fictitious states discussed in the previous section. Such groups flourish where states have failed to consolidate control over society and to co-opt domestic competitors, and where people have relied on alternative models of political organization. ${ }^{112}$

1949, 75 U.N.T.S. 135 (providing that those eligible for prisoner of war status include: (2) Members of other militias and members of other volunteer corps, including those of organized resistance movements, belonging to a Party to the conflict and operating in or outside their own territory, even if this territory is occupied, provided that such militias or volunteer corps, including such organized resistance movements, fulfill the following conditions:

(a) that of being commanded by a person responsible for his subordinates;

(b) that of having a fixed distinctive sign recognizable at a distance;

(c) that of carrying arms openly;

(d) that of conducting their operations in accordance with the laws and customs of war).

109. See WetTBERG, supra note 104, at 65-66 (also arguing that the organizational structure is irrelevant to the issue of recourse to force against non-state actors).

110. Muhammad ibn Khaldun. The MuQaddimah: An Introduction (N.J. Dawood ed., Franz Rosenthal trans., Princeton University Press 1969).

111. Brian Bennett and Robyn Dixon, U.S. Sending Military Advisors to Uganda, L.A. TimES, Oct. 15, 2011, available at $\mathrm{http} / /$ articles.latimes.com/2011/oct/15/world/la-fg-us-uganda-20111015.

112. See Sheri Berman, From the Sun King to Karzai: Lessons for State Building in Afghanistan, 89 FOREIGN AFFAIRS 2 (2010) (comparing state building in $17^{\text {th }}$ century France and $21^{\text {st }}$ century Afghanistan through combinations of coercion and cooption applied by central elites against regional warlords). 
The presence of such independent armed forces on the territory of a state compromises its positive sovereignty because it violates the "one army rule" of effective statehood. Whether by consent or ineptitude, the state has failed to maintain its monopoly on the use of force.

The prevalence of non-state actors exposes the inadequacy of a strictly state-centric security regime. These armed groups also represent an international constitutional challenge. They belie the formal leveling that accompanied decolonization $^{113}$ insofar as they demonstrate that formal equality has not resulted in substantive equality, even with respect to the most fundamental attributes of statehood. Therefore, an international system premised upon the formal equality of states fails doubly; it fails to account for fictitious statehood and it fails to respond to the threat posed by non-state actors. The opinions of the ICJ in Armed Activities on the Territory of the Congo (Dem. Rep. Congo v. Uganda), 2005 I.C.J. 168 (Dec. 19) illustrate this failure.

\section{Armed Activities: The State-Centric Paradigm vs. Reality}

The International Court of Justice's opinion in Armed Activities on the Territory of the Congo (Dem. Rep. Congo v. Uganda), 2005 I.C.J. 168 (Dec. 19), epitomizes the commitment to fictitious statehood and adherence to a rigidly state-centric interpretation of the right of self-defense. The hallmarks of this paradigm are: 1) the primacy of the central authorities, no matter how feckless they are; and 2) the dispositive consent of these authorities with respect to lawful military intervention.

Armed Activities arose out of the complex, multi-party conflict in the territory of DRC. There, "rebel groups were able to operate 'unimpeded' in the border region between the DRC and Uganda 'because of its mountainous terrain, its remoteness from Kinshasa (more than 1,500 km), and almost complete absence of central government presence or authority in the region during President Mobutu's 32-year term in office'". ${ }^{114}$ After Mobuto Sese Seko's fall, the security situation deteriorated even further. By 2001, six states and a number of militias were embroiled in a fluid, multisided conflict characterized by the opportunistic exploitation of the DRC's natural resources and widespread atrocities against civilians, including the deaths of millions. ${ }^{115}$

In this context, Uganda claimed it could lawfully intervene to counter the threat posed by one militia, the Allied Democratic Forces ("ADF"), which was operating from Congolese territory. Uganda maintained that intervention was

113. See JACKSON, supra note 3, at 14 .

114. Armed Activities on the Territory of the Congo (Dem. Rep. Congo v. Uganda), 2005 I.C.J. at $\uparrow 301$.

115. René Lemarchad, The Democratic Republic of the DRC: From Failure to Potential Reconstruction, in STATE FAILURE AND STATE WEAKNESS IN A TIME OF TERROR 29, 30 (Robert I. Rotberg ed., 2003). 
lawful on the basis of both: 1) the consent of the authorities in Kinshasa, and 2) self-defense. ${ }^{116}$ As a matter of self-defense, Uganda justified its entry into the Congolese conflagration on the grounds that its own "security situation had become untenable" because "the successive governments of the DRC ha[d] not been in effective control of all the territory of the DRC" 117 and because of the "political and administrative vacuum" in the eastern DRC. ${ }^{118}$ Uganda observed that "[t]he fissiparous tendencies of the dysfunctional Congolese state inherited from President Mobutu, which President Kabila's government had barely papered over, were set loose by the rebellion, and the central government soon lost effective control over the eastern half of the country." 119 In light of the lawlessness in the eastern DRC, Uganda argued that it was necessary to resort to the cross-border use of force in order to prevent further attacks by ADF fighters, who had previously attacked civilian targets inside Uganda. Although Uganda invoked the DRC's lack of effective control, it premised its right to self-defense upon the fact that the DRC had "not only a duty to refrain from providing any support to groups carrying out subversive or terrorist activities against another State, but also a duty of vigilance to ensure that such activities are not tolerated." ${ }^{120}$ Invoking Corfu Channel, (U.K. v. Albania), 1949 I.C.J. 4 (Apr. 9), ${ }^{121}$ Uganda contended that the DRC's failure to discharge this duty rendered the DRC responsible for the attacks of the ADF. Thus, Uganda relied upon the DRC's lack of effective control as evidence of the DRC's negligence and hence, wrongfulness, rather than the DRC's compromised sovereignty.

Having established that certain aspects of Uganda's presence were nonconsensual and that Uganda had violated the DRC's negative sovereignty, the Court considered whether such a violation could be justified on the grounds of self-defense. It rejected Uganda's claim of self-defense and, in so doing, implicitly rejected a reading of Article 51 that would accommodate the right to use cross-border force against non-state actors in self-defense. The Court observed that "in order to ascertain whether Uganda was entitled to engage in military action on Congolese territory in self-defense, it is first necessary to examine" the connection between the militias and the Congolese state (such as it was). ${ }^{122}$ In the Court's view, Uganda's right to self-defense was contingent upon the responsibility of the DRC for the actions of the non-state actors. Absent such a

\footnotetext{
116. Armed Activities on the Territory of the Congo (Dem. Rep. Congo v. Uganda), 2005 I.C.J. at 94.

117. Id. at 9109

118. See, e.g., Counter-Memorial of Uganda, Armed Activities on the Territory of the Congo (Dem. Rep. Congo v. Uganda), 2005 I.C.J. 168, 1 ฯ 52-53 (Apr. 21, 2001).

119. Id. at 945 .

120. Armed Activities on the Territory of the Congo (Dem. Rep. Congo v. Uganda), 2005 I.C.J. at $₫ 277$.

121. Corfu Channel (U.K. v. Albania), 1949 I.C.J. 4 (Apr. 9).

122. Armed Activities on the Territory of the Congo (Dem. Rep. Congo v. Uganda), 2005 I.C.J. at $\llbracket 120$.
} 
connection, "the Court [found] that the legal and factual circumstances for the exercise of a right of self-defense by Uganda against the DRC were not present." 123

Thus, the Court only addressed the issue of Uganda's right to self-defense $v i s-\grave{a}$-vis the DRC. It refused to consider whether Uganda enjoyed a right to selfdefense vis-à-vis the ADF or other armed groups operating independently in the anarchic environment of the eastern DRC. ${ }^{124}$ However, the judges pointed to the limitations of the state-centric regime governing the use of force when they stated that they were "uncomfortable being confronted with certain questions of utmost importance in contemporary international relations." 125

Though a majority of the Court rigidly adhered to a state-centric paradigm for the use of force, two judges criticized the Court's unwillingness to confront reality. The separate opinions of Judges Kooijmans and Simma reflect an appreciation for the reality of violent non-state actors and the role of state practice and opinio juris in shaping international law. Judge Kooijmans observed that:

The Parties to the present dispute share a hapless post-decolonization history .... In this respect the Parties shared the plight which seems to have become endemic in much of the African continent: régimes under constant threat from armed movements often operating from the territory of neighboring States, whose governments sometimes support such movements but often merely tolerate them since they do not have the means to control or repel them. The latter case is one where a government lacks power and consequently fails to exercise effectively its territorial authority; in short, there is a partial failure of State authority and such failure is badly concealed by the formal performance of State functions on the international level. Commitments entered into by governments unable to implement them are unworthy of reliance from the very start and hardly contribute to the creation of more stability. ${ }^{126}$

Judge Kooijmans observed that the Judgment of the Court "inadequately reflects the structural instability and insecurity in the region, the overall pattern of lawlessness and disorder." ${ }^{127} \mathrm{He}$ noted that:

Article 51 merely conditions the exercise of the inherent right of self-defense on a previous armed attack without saying that this armed attack must come from an-

123. Id. at 9147

124. See Armed Activities on the Territory of the Congo (Dem. Rep. Congo v. Uganda), 2005 I.C.J. 168, I 26 (Dec. 19) (separate opinion of Judge Kooijmans) ("The Court only deals with the question whether Uganda was entitled to act in self-defense against the DRC and replies in the negative since the activities of the rebel movements could not be attributed to the DRC. By doing so, the Court does not answer the question as to the kind of action a victim State is entitled to take if the armed operation by irregulars, because of its scale and effects, would have been classified as an armed attack rather than as a mere frontier incident had it been carried out by regular armed forces but no involvement of the host government can be proved") (internal quotations omitted).

125. Armed Activities on the Territory of the Congo (Dem. Rep. Congo v. Uganda), 2005 I.C.J. 168, 15 (Dec. 19) (separate opinion of Judge Simma).

126. Armed Activities on the Territory of the Congo (Dem. Rep. Congo v. Uganda), 2005 I.C.J. at 5 (separate opinion of Judge Kooijmans) (emphasis added).

127. Id. at $\llbracket 14$. 
other State even if this has been the generally accepted interpretation for more than 50 years. I also observed that this [state-centric] interpretation no longer seems to be shared by the Security Council, since in resolutions 1368 (2001) and 1373 (2001) it recognizes the inherent right of individual or collective selfdefense without making any reference to an armed attack by a State. In these resolutions the Council called acts of international terrorism, without any further qualification and without ascribing them to a particular State, a threat to international peace and security. ${ }^{128}$

Judge Koojimans further opined that the case arose in a context "which in present-day international relations has unfortunately become as familiar as terrorism, viz. the almost complete absence of government authority in the whole or part of the territory of a State. If armed attacks are carried out by irregular bands from such territory against a neighboring State, they are still armed attacks even if they cannot be attributed to the territorial State."129 These nonstate actors may pose a security threat equal to that of states. Therefore,

The lawfulness of the conduct of the attacked State must be put to the same test as that applied in the case of a claim of self-defense against a State: does the armed action by the irregulars amount to an armed attack and, if so, is the armed action by the attacked State in conformity with the requirements of necessity and proportionality." 130

Judge Simma also criticized the restrictive reading of Article 51 as inconsistent with the current state of international law.

Such a restrictive reading of Article 51 might well have reflected the state, or rather the prevailing interpretation, of the international law on self-defense for a long time. However, in the light of more recent developments not only in State practice but also with regard to accompanying opinio juris, it ought urgently to be reconsidered, also by the Court. As is well known, these developments were triggered by the terrorist attacks of September 11, in the wake of which claims that Article 51 also covers defensive measures against terrorist groups have been received far more favorably by the international community than other extensive rereadings of the relevant Charter provisions, particularly the "Bush doctrine" justifying the pre-emptive use of force. Security Council resolutions 1368 (2001) and 1373 (2001) cannot but be read as affirmations of the view that large-scale attacks by non-State actors can qualify as "armed attacks" within the meaning of Article 51.131

Thus, Judges Kooijmans and Simma acknowledged the reality of a world of fictitious states and non-state actors and interpreted the Charter accordingly. The judges recognized that the right of self-defense applied to actions taken against non-state and state actors.

However, the Judges erred by suggesting that 9/11 expanded the scope of this customary right. As the next Part illustrates, the customary right of self-

128. Id. at 928.

129. Id. at 930 (internal quotations omitted).

130. $I d$. at 931.

131. Armed Activities on the Territory of the Congo (Dem. Rep. Congo v. Uganda), 2005 I.C.J. at 11 (separate opinion of Judge Simma). 
defense predates $9 / 11$ and has encompassed actions against non-state actors for two centuries. Violent non-state actors operating from fictitious states have long threatened the security of states, which have often responded to this threat through the use of military force across international borders. The next Part examines international incidents involving the use of force against non-state actors in ungoverned territory and analyzes the legal claims made by states to justify such actions. These incidents place current security threats posed by groups like Al Qa'ida in Yemen or Pakistan in their historical context. These legal claims also reveal a consistent set of principles that justify military action.

III.

\section{StATE ResPonse: THE Other FACE OF EFFeCtive CONTROL}

Customary international law has long accommodated the need to respond to threats from violent non-state actors through a right of self-defense. Historically, governments have been unwilling to tolerate security threats posed by independent violent non-state actors who exploit gaps in state control. Consequently, there is a long history of the use of force against non-state actors and a correspondingly long history of justifications premised upon self-defense in the face of state ineffectiveness.

This body of state practice, opinio juris, and the reactions of other states indicate that self-defense against non-state actors was lawful at the time of the Charter's drafting. Legal justifications of the pre- and post-Charter eras demonstrate substantial continuity. This history shows that governments were mindful of practical deficiencies in state authority and willing to use self-help to enforce the international legal obligations of other states who were unwilling or unable to do so themselves.

Regardless of whether a state is unwilling or unable to evict violent nonstate actors, the presence of non-state actors nevertheless compromises state sovereignty. A state cannot claim a monopoly on violence if an independent armed force is present within its nominal territory. Forceful intervention by the defending state amounts to "extraterritorial law enforcement"132 because the defending state is enforcing the international obligations of the fictitious state.

This Section examines state practice, self-defense justifications, and, where possible, the responses of other governments to these claims of self-defense. It reviews incidents in which the defending state implicitly or explicitly invokes state ineffectiveness or otherwise emphasizes deficiencies in state control. This tacit acknowledgement of fictitious statehood by governments generally serves one of two purposes. Governments either raise state incapacity or unwillingness to justify the use of defensive force as a necessity, or governments cite host state ineffectiveness as a waiver of the host state's negative sovereignty.

132. See Yoram Dinstein, War, Aggression, And Self-Defense 206-206, 244 (4th ed. 2005). 
Such claims premised upon state ineffectiveness invert the ICJ's "effective control" test for state responsibility. ${ }^{133}$ Rather than justifying military action based on the effective control of a state over a violent non-state actor, states justify the defensive use of force based on the host state's lack of effective control over its nominal territory. From the post-colonial perspective, these claims are radical because they reassert the connection between positive and negative sovereignty. To claim their right to exclude, states must demonstrate their ability to control.

During the nineteenth and early twentieth centuries, the United States repeatedly resorted to defensive force in response to threats posed by violent nonstate actors operating from lawless regions across its borders. Whether justified as defensive, preventative, precautionary, or punitive, these actions all had the same stated end: abating this threat. These interventions contributed to the establishment of an international historical pattern and a legal framework for state response to lawlessness and international terrorism that persists today.

\section{A. United States and Spanish Florida}

The modern template for intervention against non-state actors operating from ungoverned territory dates to 1817 , when US military forces under the command of Andrew Jackson launched an expedition into Spanish Florida. US forces fought against armed bands of Seminole Indians that had been instigated by British military officers. ${ }^{134}$ Commenting on the legal basis for the United States' use of force on Spanish territory, Jackson observed to Secretary of War John C. Calhoun that "[t]he Spanish Government is bound by treaty . . . to keep her Indians at peace with us. They have acknowledged their incompetency to do this, and are consequently bound, by the law of nations, to yield us all facilities to reduce them."135 Jackson's invocation of a longstanding legal framework demonstrates that the right of self-defense against non-state actors was already an established component of international law by the early nineteenth century. The 1817 incident merely re-asserted those pre-existing norms and it applied them to relations between emerging modern states, non-state territorial entities, and violent non-state actors.

Further illuminating this reasoning, Secretary of State John Quincy Adams later described the legal basis for US action in a similar fashion:

He [General Jackson] took possession, therefore, of [Spanish territory] . . not in a spirit of hostility to Spain, but as a necessary measure of self-defense; giving notice that they should be restored whenever Spain should place commanders and a force there able and willing to fulfill the engagements of Spain towards the

United States, or of restraining by force the Florida Indians from hostilities

133. Military and Paramilitary Activities (Nicar. v. U.S.), 1986 I.C.J. at 9115.

134. Moore, supra note 30, at Vol. 2, 403 (emphasis added).

135. Id. 
against their citizens. ${ }^{136}$

The legal claims advanced by the United States are notable because they emphasize the following: 1) Spanish "incompetence," 2) the distinction between the armed bands and Spain, and 3) a good-faith willingness to cooperate with Spanish authorities to restore Spain's effective control over the affected area. Spain implicitly accepted this reasoning and did not contest the lawfulness of the incursion itself. Instead, Spain's protests to the United States focused on the plundering and destruction of Spanish property that accompanied the intervention. ${ }^{137}$ In short, Spain contested the jus in bello rather than the jus ad bellum of the American action.

In 1817, American forces also launched an incursion into Spanish territory off the eastern coast of Florida. Amelia Island had fallen under the control of Gregor McGregor and a band of what President James Monroe described as "adventurers from different countries, with very few, if any of the native inhabitants of the Spanish colonies." 138 Secretary of State Adams justified the United States' use of force against Amelia Island, arguing:

When an island is occupied by a nest of pirates, harassing the commerce of the United States, they may be pursued and driven from it, by authority of the United States, even though such island were nominally under the jurisdiction of Spain, Spain not exercising over it any control. ${ }^{139}$

Once again the United States emphasized the threat it was responding to and the necessity of using force. In this case, however, Spain's lack of control over Amelia Island appears to have mitigated any violation of its negative sovereignty by the United States. Spain, as well as the putative representative of Spain's then-renegade colonies, protested US action. ${ }^{140}$ However, diplomatic correspondence reveals that the United Kingdom and other major powers expressed "no dissatisfaction" with US occupation of the island. ${ }^{141}$

\section{B. The Caroline Incident: The United States of Ineffectiveness}

The United States has not always been the defending state in international incidents involving military response to violent non-state actors. The Caroline incident described below reveals that the United States does not invoke principles it is unwilling to apply to itself. The United States has itself, at times, lost effective control over its territory, thereby permitting the presence of independent armed groups.

During the British suppression of an 1837 insurrection in southern Canada,

136. Id. at 405-06.

137. Id. at 404 .

138. Id. at 408

139. Id.

140. Id.

141. Id.; see also Reisman, Private Armies in a Global War System, supra note 48, at 252, 256. 
Canadian rebels sought refuge across the border in New York State. ${ }^{142}$ The rebels recruited American sympathizers to gather private arms and pillage the armory at Batavia, New York, making off with several hundred weapons, including two field artillery pieces. ${ }^{143}$ In a letter to the President, the mayor of Buffalo complained that " $[t]$ he civil authorities have no adequate force to control these men, and unless the General Government should interfere, there is no way to prevent serious disturbances." 144

The "General Government" did not interfere and the Canadian-American insurrection went on to occupy Navy Island, a Canadian island in the Niagara River. ${ }^{145}$ From the island these forces repeatedly engaged in "Acts of Warlike aggression on the Canadian shore, and also on British Boats passing the Island." 146 The insurrectionists also manned a steamer, the Caroline, to provision (especially with munitions) the forces encamped on the island. British authorities alerted the government of New York of the threat posed to British territory and subjects by the lawlessness in New York, but they received no reply. ${ }^{147}$

With the local authorities unable to control their territory and population and the state and federal authorities uninterested in asserting control, Britain resorted to unilateral force to prevent future attacks. On the night of December 29, 1837, while the Caroline was docked on the American bank of the river, British forces assaulted the vessel. ${ }^{148}$ They killed and wounded several of the Americans onboard and sent the Caroline over Niagara Falls in flames. ${ }^{149}$

During the diplomatic row that ensued, the governments of the United States and Britain established what would become the defining principles of lawful self-defense against state and non-state actors in customary international law. The British justified their incursion into American territory on the basis of: 1) the threat posed by the Caroline, 2) the insurrectionists' status as an independent armed force, and 3) the United States' lack of effective control over its own territory and populace. ${ }^{150}$ Henry Stephen Fox, the British Minister in Washington, replied to a complaint by the US Secretary of State by citing both the "piratical character of the steam boat 'Caroline,' and the necessity of selfdefense and self-preservation." ${ }^{151}$ Moreover, Fox noted that:

At the time when the event happened, the ordinary laws of the United States were not enforced within the frontier district of the State of New York. The authority

142. R.Y. Jennings, The Caroline and McLeod Cases, 32 AM. J. INT'L. L. 82 (1938).

143. Id. at 83 (citing H. Ex. Doc. No. $74,25^{\text {th }}$ Cong., $2^{\text {nd }}$ Sess.).

144. Id. at $86 \mathrm{n} .12$ (citing H. Ex. Doc. No. $74,25^{\text {th }}$ Cong., 2d Sess.).

145. Id. at 83 .

146. Id. (citing Law Officer's Report, Feb. 21, 1838).

147. Id.

148. Id. at 84 .

149. MOORE, supra note 30, at Vol. 2, 409.

150. Jennings, supra note 142 , at 85 .

151. H. R. Exec. Doc. No. 2-302, at 3 (1838). 
of the law was overborne, publicly, by piratical violence .... This extraordinary state of things appears, naturally and necessarily, to have impelled them [Canadian armed forces] to consult their own security, by pursuing and destroying the vessel of their piratical enemy, wheresoever they might find her." 152

Thus, the United States' lack of effective control necessitated Britain's resort to defensive force.

In a report to the British Foreign Minister, the legal officers of Britain's Foreign Office emphasized both the necessity for intervention in the Caroline incident and the precautionary motive behind Britain's actions. The report stated: "We feel bound to suggest to your Lordship that the grounds on which we consider the conduct of the British Authorities to be justified is that it was absolutely necessary as a measure of precaution for the future and not as a measure of retaliation for the past. What has been done previously is only important as affording irresistible evidence of what would occur afterwards." ${ }^{153}$ In other words, the lawfulness of British action hinged upon the fact that it was intended to prevent future harm, and not to serve as revenge for prior injury.

In a letter to Lord Ashburton, US Secretary of State Daniel Webster acknowledged the potential lawfulness of cross-border defensive measures against non-state actors. ${ }^{154}$ However, in his famous formulation, Webster established a high bar for the legitimacy of such action: hostile acts "within the territory of a party at Peace" could only be justified by "clear and absolute necessity." 155 Moreover, Webster wrote that the "necessity of [that] self-defense . . . [is] instant, overwhelming, leaving no choice of means, and no moment for deliberation." ${ }^{156}$ Even if such necessity authorized British authorities to enter US territory, Webster argued, their actions were only lawful if they "did nothing unreasonable or excessive; since the act, justified by the necessity of self-defense, must be limited by that necessity, and kept clearly within it." 157

In his reply, Ashburton accepted Webster's framework for lawful selfdefense. ${ }^{158} \mathrm{He}$ argued that the necessity prong was satisfied due to the lack of effective control by the American authorities. ${ }^{159}$ Given this lack of control, Ashburton reasoned, appeal to the American authorities would have been futile. Ashburton wrote, "I might safely put it to any candid man, acquainted with the existing state of things, to say whether the military commander in Canada had the remotest reason ... to expect to be relieved from this state of suffering by

152. Id.

153. Jennings, supra note 142, at 87 (quoting 61 Parliamentary Papers (1843)); 30 B.S.P. 193.

154. Id. at 89 .

155. Daniel Webster, The Papers of Daniel Webster Series 3: Diplomatic Papers, Vol. 1, 1841-1843, 62 (Kenneth Shewmaker ed., 1983).

156. Jennings, supra note 142, at 89.

157. Id.

158. Id.

159. Id. at 90 . 
the protective intervention of any American authority[.]" ${ }^{160} \mathrm{He}$ argued that the lack of alternative means necessitated the use of military force and that the British nighttime raid and destruction of the vessel was a proportional response to the threat. Furthermore, he maintained that the timing of the raid and the loosing of the flaming vessel over the falls were proportional because they would minimize both the loss of life and damage to other property. ${ }^{161}$

Webster noted that this narrow exception to the "inviolable character of the territory of independent states ... [grew] out of the great law of selfdefense." $162 \mathrm{He}$ further observed that the governments of the United States and the United Kingdom agreed on the legal standard for self-defense, but disagreed as to whether the "facts in the case of the Caroline make out a case of such necessity for the purposes of self-defense."163

The Caroline incident is particularly significant for the law of self-defense against non-state actors. The British did not attempt to justify intervention on the basis of American responsibility for the Caroline but New York State's (admitted) lack of effective control over its own territory. Both Britain and the United States agreed in principle to the existence of a right to self-defense against nonstate actors. They also agreed that such a right could justify the violation of another state's negative sovereignty. Moreover, a prior armed attack was merely additional evidence of the existence of a security threat that necessitated the use of force. Thus, such self-defense was forward looking insofar as its purpose was aimed to future harm, and not to retaliate for past wrongs.

\section{United States and Mexico: Ungoverned Space on the Border}

During the nineteenth century, the United States repeatedly resorted to cross-border incursion into Mexico in response to threats posed by "predatory Indians and other marauders." 164 In 1836, Secretary of State John Forsyth wrote to his Mexican counterpart explaining that any US military incursion into Mexico was entirely on the basis of self-defense and emphasized that force was not directed towards the Mexican state.

Should the [American] troops, in the performance of their duty, be advanced beyond the point Mexico might suppose was within the territory of the United States, the occupation of the position was not to be taken as an indication of any hostile feeling, or of a desire to establish a possession or claim not justified by the treaty of limits, [but only as] precautionary and provisional, [to be] abandoned whenever the disturbance in that region should cease, they being the only motive for it. ${ }^{165}$

160. Id. at 90 (citing 61 PARL. DEB., H.C. (3d ser.) (1843) (U.K.); 30 B.S.P. 195).

161. Id.

162. MoORE, supra note 30, at Vol. 2, 412.

163. Id.

164. Id. at 418 .

165. Id. at 418 . 
Forsyth elaborated upon the United States' legal position in a letter to the American ambassador to Mexico. The letter emphasized that intervention into Mexico rested "upon principles of the law of nations, entirely distinct from those on which war is justified - upon the immutable principles of self-defense-upon the principles which justify decisive measures of precaution to prevent irreparable evil to our own or to a neighboring people."166

The United States' right to self-defense against the non-state threat entailed preemptive action. In justifying proactive action, Forsyth argued that:

Our fellow-citizens . . . are to be exposed to massacre . . . and the whole frontier to be laid waste by those savages Mexico was bound to control. Until these evils happen, on Mr. Gorostiza's theory, we have no right to take a position which will enable us to act with effect; and before we do act . . . after the frontier has been desolated, we must demand redress of Mexico, wait for it to be refused, and then make war upon Mexico. We are quietly to suffer injuries we might prevent in the expectation of redress - redress from irreparable injuries from Mexico, who did not inflict them, but who was, from circumstance, without the power to prevent . . . . To make war upon Mexico for this involuntary failure to comply with her obligations, would be equivalent to an attempt to convert her misfortunes into crimes-her inability into guilt. 167

The United States' legal claim: 1) differentiated between the Mexican state and non-state actors, 2) premised self-defense upon the necessity arising from Mexico's lack of effective control, and 3) emphasized that American action was preventative or precautionary.

Mexico did not receive the American legal claim well. ${ }^{168}$ In light of Texas' subsequent admission into the United States and the Mexican Cession of 1848 following the Mexican-American War, Mexico may have had real concerns over the sincerity of any American disavowal of territorial designs. In short, Mexico rejected the United States' legal claims because it deemed them pretextual, and thus the United States' recourse to force as unnecessary.

Twenty years later, a company of Texas Rangers pursued into Mexico a band of Mexican natives that had launched a raid into Texas. In a letter to his Mexican counterpart, Secretary of State William Marcy asserted that international law allowed such hot pursuit in self-defense and that the United States would not complain if Mexico launched, out of necessity, similar proportionate incursions into the United States.

If Indians whom the United States are bound to restrain shall, under the same circumstances, make a hostile incursion into Mexico, this Government will not complain if the Mexican forces who may be sent to repel them shall cross to this side of the line for that purpose, provided that in so doing they abstain from injuring the persons and property of the citizens of the United States. ${ }^{169}$

\footnotetext{
166. Id. at 420 (emphasis added).

167. Id. at 420-421.

168. Id. at $418-420$.

169. Id. at 421 .
} 
It is thus clear that the United States was not claiming for itself a right it was unwilling to grant other states. As subsequent Secretary of State Hamilton Fish observed to the Secretary of War William Belknap, "[a]n incursion into the territory of Mexico for the purpose of dispersing a band of Indian marauders is, if necessary, not a violation of the law of nations."170

President Buchanan went a step further and proposed the establishment of a temporary protectorate in areas of "anarchy and violence" of Northern Mexico. ${ }^{171}$ The government would withdraw American forces "as soon as local governments shall be established in these Mexican States capable of performing their duties to the United States, restraining the lawless, and preserving peace along the border." 172 Again, the United States based this claim of necessity upon Mexico's lack of effective control over its nominal territory.

Lawlessness in Mexico was also the basis for the United States' most famous incursion into Mexico: John Pershing's 1916 pursuit of Francisco "Pancho" Villa, following Villa's attack upon Columbus, New Mexico. The United States initially justified Pershing's expedition on the basis of both defensive reprisal and the consent of the Mexican state. President Woodrow Wilson publicly announced that, "the expedition into Mexico was ordered under an agreement with the de facto government of Mexico for the single purpose of taking the bandit Villa ... and is in no sense intended as an invasion of that republic or as an infringement of its sovereignty." 173 Wilson also asserted that "[t]he expedition is simply a necessary punitive measure, aimed solely at the elimination of the marauders who raided Columbus and who infest an unprotected district near the border which they use as a base in making attacks upon the lives and property of our citizens with our own territory."174 Wilson's reasoning clearly indicates that his use of "punitive" is best understood as precautionary, and not as retaliatory: the purpose of the "punitive measure" is "solely . . . the elimination of the marauders." The general consent of the de facto government of Mexico for the US military expedition was based on the prior reciprocal agreement between the two countries permitting hot pursuit of "bandits" across the international border into the United States. ${ }^{175}$ The United States renewed its commitment to this agreement hoping to "suppress this state of lawlessness . . . in the regions contiguous to the boundary between the two Republics." 176 In a parallel to the current US involvement in Pakistan, the Mexican state subsequently publicly denied consenting to the presence of the US military in its territory. The United States replied by "vigorously defending its action in protecting

170. $I d$.

171. Id.

172. Id.

173. George Finch, Mexico and the United States, 11 AM. J. INT’L L. 399, 399-400 (1917).

174. Id. at 400 .

175. Green Haywood Hackworth, Digest of InTERnational LAW 292-293 (1940).

176. Id. at 292. 
its border by patrolling a portion of Mexico" where the Mexican state "was obviously unable to exert any semblance of authority", and the United States refused to withdraw until Mexico "gave evidence of some ability to fulfill his international obligations to his neighbor on the north." 177 Writing to his Mexican counterpart, US Secretary of State Robert Lansing decried the persistent inability of the Mexican state to repress the "marauding attacks" across the international border. ${ }^{178}$ Such ineffectiveness "may excuse the failure to check the outrages complained of, but it only makes stronger the duty of the United States to prevent them." 179

A bilateral commission eventually negotiated the withdrawal of American forces, contingent on their immediate replacement by Mexican troops and the "occupation and protection of territory evacuated by the American forces." 180 The American members of the commission also insisted that the United States reserved "the right to pursue marauders coming from Mexico into the United States so long as conditions in northern Mexico are in their present abnormal condition. Such pursuit is not however, to be regarded by Mexico as in any way hostile to the Carranza Government, for these marauders are our common enemies." 181 Despite Mexican authorities' poor reception of the agreement, US forces withdrew by early $1917 .^{182}$

Pershing's expedition is notable because the United States premised its legal claim upon the necessity of self-defense arising from Mexico's lack of effective control over the territory of Northern Mexico. In such a power vacuum the United States was entitled to fulfill the international legal obligations neglected by Mexico. Nonetheless, the United States took pains to distinguish between Pancho Villa and the Mexican state and did not justify the expedition on the grounds of Mexican responsibility. Like his predecessor, Secretary of State Forsyth, Lansing distinguished between Mexican wrongfulness (failure to control its nominal territory) and the threat posed by "bandits." 183

\section{Soviet Union: Civil War Spillover}

Further confirming the existence of a customary law right, defensive actions premised upon state weakness were not merely the preserve of western, capitalist states. The Soviet Union repeatedly resorted to cross-border force against White Guard forces in order to prevent "acts of aggression." ${ }^{184}$ In a

177. Finch, supra note 173 , at 401.

178. HACKWORTH, supra note 175, at 297.

179. Id.

180. Finch, supra note 173, at 403.

181. Id. at 404.

182. Id. at 405 .

183. HACKWORTH, supra note 175, at 297.

184. Note from Chicherin and Rakovsky to the Rumanian Foreign Minister on Anti-Soviet Or- 
1921 note to the Romanian Foreign Minister, the Soviet Government wrote that:

In its desire to assist the Rumanian authorities to disperse the bands organized in Bessarabia and Rumania for the purposes of carrying out acts of aggression against the Soviet Republics, the allied Soviet Government consider it necessary that if such bands, when pursued by Soviet troops, should cross into territory occupied by the Rumanian authorities, they should be followed into this latter territory, the Rumanian authorities being informed in time so that the operations . . . shall not be interpreted as acts directed . . . against the Rumanian Government and people." 185

Thus, the Soviet Government implied that recourse to force was necessary because Romania was incapable of dispersing the White Guards on its territory. As with the earlier US incursions into Mexico, the Soviet Union took pains to differentiate between the target non-state actor and the Romanian state and population and to emphasize that force was directed against the former and not the latter.

In 1921, the Red Army also attacked White Russian forces based in Outer Mongolia, which was under the nominal sovereignty of the post-Qing Chinese Republic. The anti-Bolshevik forces had established themselves in Mongolia at a time when central authority in China was exceedingly weak and warlords held local power. ${ }^{186}$ In a 1925 note to the Chinese Foreign Minister, the Soviet Government argued, in tones reminiscent of the earlier diplomatic exchanges involving the United States, Britain, and Mexico, that it had resorted to force only after exhausting all other options.

Repeated requests addressed to the Chinese Government for the liquidation of the White Guard bands of Semenov, Ungern, and others, freely operating and organizing on the territory of Mongolia, led to no positive results, as the Chinese Government was indifferent to these urgent appeals by the Soviet Government. In view of this in the interest of the safety of its frontiers the Soviet Government was constrained to conduct part of the Red Army into Mongolian territory and liquidate all the White Guard bands and organizations which, organized and supported by foreign imperialism, were preparing to invade the Soviet Republic once more from Mongolia. After the liquidation of the White Guard armies part of the Red Army remained in Mongolia in the interest of the preservation of order and for the purpose of preventing the organization of White bands as a new menace to the safety of the USSR. ${ }^{187}$

As with the United States and Britain, the Soviet Union resorted to force when its neighbors were unwilling or unable to control their own territories and it defended such actions on the basis of self-defense.

ganizations in Rumania (August 13, 1921), in 1 SOvIET DocumENTS ON ForeIGN POLICY, 253-254 (Jane Degras ed., 1951).

185. Id.

186. See Kimberly Marten, Warlordism in Comparative Perspective, 31 InT'L SECURITY 41 (2006) (drawing parallels between warlordism in China, Afghanistan, Somalia and Medieval Europe).

187. Note from Karakhan, Soviet Ambassador in Peking, to the Chinese Foreign Minister on the Withdrawal of Soviet Troops from Outer Mongolia, in 2 SOvIET DocumENTS ON ForeIGN POLICY, 253-254 (Jane Degras ed., 1952). 


\section{E. $1945-2001$}

Notwithstanding the reification of fictitious statehood during decolonization, fictitious states did not disappear as a result of these good intentions. Nor did violent non-state actors disappear, bred as they were by these newly minted states. As a result, states continued to resort to force against non-state actors, and they continued to emphasize a state's lack of control as a key factor necessitating self-help. The post-Charter justifications for such uses of force echo many of the legal claims made in the pre-Charter era. These claims indicate that, though the governments of defending states may have been willing to tolerate fictional statehood and negative sovereignty in general, they often justified actual defensive measures by citing a lack of effective control.

At least in principle, many major powers accepted such recourses to defensive force as lawful. This acceptance - or at least acquiescence-reflects the survival of the customary right of self-defense against non-state actors in the post-Charter era. However, some governments, particularly those of the former colonies and their Communist backers, generally rejected any claim of selfdefense against non-state actors, whether or not premised upon state ineffectiveness.

For example, as a perennial target of violent non-state actors, Israel has advanced a disproportionate number of claims of self-defense. Many former colonies and Communist states considered Israel, like South Africa and Rhodesia, to be a pariah. As a result, many states regarded Israel's claims of self-defense as per se invalid. ${ }^{188}$ Given this perceived a priori illegitimacy of any Israeli military action, an incident-based analysis of international reaction to Israel muddies the waters regarding the law of self-defense.

\section{Israel}

Israel has repeatedly invoked the absence of positive sovereignty as a justification for violating a host state's negative sovereignty. ${ }^{189}$ In 1976, Israel staged a successful commando raid on Entebbe, Uganda, to rescue Israeli hostages held by Palestinian hijackers. In the aftermath of the assault, Israel's representative wrote to the UN Secretary General justifying its use of force as selfdefense on behalf of its citizens. ${ }^{190}$ Israel argued that its incursion into Ugandan

188. Elimination of All Forms of Racial Discrimination, G.A. Res. 3379 (XXX), U.N. Doc. A/RES/3379 (Nov. 10, 1975) (stating "that the racist regime in occupied Palestine and the racist regime in Zimbabwe and South Africa have a common imperialist origin, forming a whole and having the same racist structure and being organically linked in their policy aimed at repression of the dignity and integrity of the human being").

189. The majority of instances of Israeli recourse to force in self-defense against non-state actors fall outside the scope of this article. For a more complete study, see WETtBERG, supra note 104, at 73-122, 164-165.

190. Permanent Rep. of Israel to the U.N, Letter dated July 4, 1976 from the Permanent Rep. of Israel to the United Nations addressed to the Secretary General, U.N. Doc. S/12123 (Jul. 5, 1976). 
territory was lawful because Uganda "does not exercise sovereignty over its territory and was incapable of dealing with half a dozen terrorists." 191 Thus, Israel's violation of Uganda's sovereignty was justified because Uganda did not in fact exercise sovereignty, and also because such state weakness posed a real and immediate threat to Israeli citizens. The reaction to Israel's use of force was mixed, but ultimately efforts to condemn Israel in the UN Security Council failed and Uganda made no attempt to convene the General Assembly under the "Uniting for Peace" procedure. ${ }^{192}$

In 1981, Israel again justified its actions by reference to its right to selfdefense, "a right also preserved under Article 51 of the Charter of the United Nations." 193 Israel cited the weakness of the Lebanese state as necessitating its 1981 airstrikes against Palestinian Liberation Organization (PLO) targets in Lebanon, emphasizing that "PLO domination over large parts of Lebanon and the anarchy it has created there." 194 Israel also highlighted the fact that the Lebanese state lacked "effective authority" over "large parts of its territory controlled by foreign elements." 195 Israel explicitly invoked both the Caroline incident and the Pershing's expedition into Mexico as legal precedents for Israel's defensive use of force against the PLO. ${ }^{196}$ According to Israeli authorities, the inability of the Lebanese government to control its territory necessitated Israel's recourse to force. However, members of the Security Council states rejected Israel's justification of self-defense because they deemed its military measures to be preemptive and disproportionate. ${ }^{197}$

Israel also cited the gap between positive and negative sovereignty when it justified its 1982 invasion of Lebanon. It first cited the necessity of defending itself against attacks by the PLO. ${ }^{198}$ Israel argued that the invasion of Lebanese territory was a lawful defensive response because Lebanon had "lost much of its sovereignty over its own territory to the terrorist PLO." 199

The United Nations, however, deemed Israel's 1982 invasion unlawful. The UN Security Council unanimously adopted a resolution demanding that "Israel withdraw its forces forthwith." 200 The General Assembly, convened under the

191. U.N. SCOR, 31st Sess., $1939^{\text {th }}$ mtg. at 7, U.N. Doc. S/PV.1939 (Jul. 9, 1976).

192. THOMAS FrANCK, RECOURSE TO FORCE 83-85 (2002).

193. U.N. SCOR, 36th Sess., 2292d mtg. at 5, U.N. Doc. S/PV.2292 (July 17, 1981).

194. Id. at 5 .

195. Id. at 6 .

196. William Claiborne, Begin Widens Targeting to PLO Sites in Cities, WASH. Post, Jul. 18, 1981, at A1.

197. U.N. SCOR, 36th Sess., 2293rd mtg. at 4, U.N. Doc. S/PV.2293 (July 21, 1981) (France criticizing Israel's action as preemptive); $I d$. at 5 (the United Kingdom criticizing the scale of Israeli action); Id. at 7 (Egypt criticizing any action that "fails to be proportionate").

198. U.N. SCOR, 37th Sess., 2375th mtg. at 3, U.N. Doc. S/PV.2375 (Jun. 6, 1982).

199. Id. at 5 .

200. S.C. Res. 509, ๆ 1, U.N. Doc. S/RES 509 (June 6, 1982). 
"Uniting for Peace" procedure, expressed alarm in a vote of 127 to 2 (with Israel and the United States casting the opposing votes) at "Israel's acts of aggression." 201 The resolution also reaffirmed the fundamental principles of Lebanese "sovereignty, territorial integrity, unity and political independence."202 Even US President Ronald Reagan deplored Israel's actions as disproportionate, a sentiment shared by many leaders. ${ }^{203}$

Israel continued to argue that state weakness necessitated self-defense in subsequent military actions. In 1988, Israel launched airstrikes against PLO targets in the Lebanese city of Sidon in response to rocket attacks by the PLO from southern Lebanon. Citing self-defense as the basis for its actions, Israel argued that its action was necessary given Lebanon's lack of effective control over its territory. "[I]n the absence of a Lebanese Government capable of assuming its responsibilities, we have no option but to take necessary measures for our security." ${ }^{204}$ Moreover, Israel contended that its "ongoing measures for self-defense . . . are restrained, they are temporary, but they are necessary." 205 The United States vetoed a proposed Security Council resolution condemning Israel. ${ }^{206}$

Israel's claim of necessity for its 1996 "Operation Grapes of Wrath" campaign against Hezbollah targets in southern Lebanon was also based upon the fecklessness of the "so-called sovereign Government of the State of Lebanon." 207 "The Lebanese Government does not have the ability — or the will to control Hezbollah activities. Therefore, Israel must defend the security of its north by all necessary measures . . . The Lebanese Government was told time and again: control the Hezbollah. If you are, as you claim, the sovereign Government of Lebanon, then this is your obligation."208 Thus once again, Israel invoked state weakness as necessitating its recourse to force.

Israel also highlighted the hypocrisy of sovereignty. "It was very strange to hear from the Prime Minister of Lebanon, just last night, that 'It is not within our ability to do this.' Please decide: either his is the sovereign Government, or

201. G.A. Res. ES-7/5, U.N. Doc. A/RES/ES-7/5 (June 26, 1982).

202. Id.

203. Hendrik Smith, Reagan Sends Begin a 'Firm' Call to Stop Fighting and Start Pullout, N.Y. TimeS, Jun. 11, 1982, available at http://www.nytimes.com/1982/06/11/world/reagan-sendsbegin-a-firm-call-to-stop-fighting-and-start-pullout.html (noting President Reagan's displeasure at the scale of Israeli military actions and the refusal to send Secretary of State Haig to Israel for talks); see also Bradley Graham, West Germans Speaking Out on Beirut Siege, WASH. Post, Aug. 15, 1982, at A23 (quoting German Chancellor Schmidt's criticism of Israel's "indiscriminate attacks"); U.N. SCOR. 37th Sess., 2377th mtg. at 3, 4, U.N. Doc. S/PV.2377 (Jun. 8, 1982) (Spain criticizing the magnitude of Israel's response); Id. at 4 (Ireland noting the lack of and "sense of proportion" in Israel's military measures).

204. U.N. SCOR, 43rd Sess., 2783d mtg. at 36, U.N. Doc. S/PV.2783 (Jan. 18, 1988).

205. Id.

206. U.N. SCOR, 43rd Sess., 2784th mtg. at 49-50, S/PV.2784 (Jan. 18, 1988).

207. U.N. SCOR, 51st Sess., 3653rd mtg. at 7, U.N. Doc. S/PV.3653 (Apr. 15, 1996).

208. Id. at 6 . 
[Vol. 30:1

it is not within its ability." 209 Both Germany and Russia criticized Israel's actions as disproportionate. ${ }^{210}$ Egypt rejected Israel's claim of self-defense and in doing so explicitly invoked the Caroline formulation. ${ }^{211}$ Israel, Egypt contended, had not exhausted other means of achieving its security objectives, and its actions were therefore unnecessary. ${ }^{212}$ Moreover, Egypt claimed that Israel's response to the threat was disproportionate. ${ }^{213}$

The contrasting international reactions to the Entebbe incident, the 1982 invasion of Lebanon, and the 1996 Grapes of Wrath operation can in part be understood in terms of proportionality. ${ }^{214}$ Many key states considered Israel's surgical and brief incursion into Uganda lawful because it was a proportionate defensive response. However, UN member states regarded Israel's full-scale invasion of Lebanon to be a disproportionate response to the PLO's cross-border raids. In that instance, Israel invaded territory beyond that from which the PLO had launched its attacks. Israel resorted to force not only in the ungoverned territory of Lebanon's south, but also in territory under the effective control of the Lebanese state. Thus, Israel violated both Lebanon's positive and negative sovereignty.

\section{Russia-Afghanistan}

Foreshadowing the events and claims of 2001, Russia cited self-defense in 1993 when it moved against militants in Afghanistan. Russian and Tajik forces repulsed an incursion by "armed formations of irregular forces of the Tajik opposition and Afghan Mujahidin" launched from Afghan territory into Tajiki$\operatorname{stan}^{215}$ Russia alleged that "responsibility for this act of banditry lies squarely with those extremist groups in Afghanistan," but it did not attribute the incursion to the Afghan state. ${ }^{216}$ Indeed, the Afghan government denied any involvement in the border incident. ${ }^{217}$ Russia and Tajikistan justified their subsequent artillery assault against targets within Afghan territory on the basis of the right of collective self-defense under Article 51 of the Charter. ${ }^{218}$ Russia concluded by

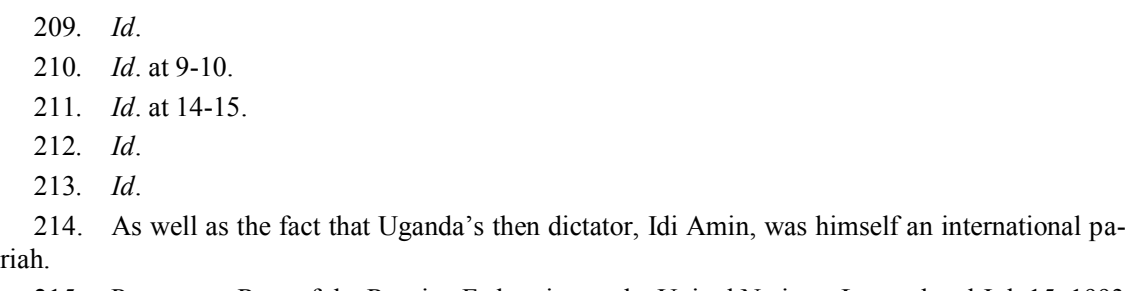

215. Permanent Rep. of the Russian Federation to the United Nations, Letter dated Jul. 15, 1993 from the Permanent Rep. of the Russian Federation to the United Nations addressed to the SecretaryGeneral, at 2, U.N. Doc. S/26110 (Jul. 15, 1993).

216. Id.

217. Permanent Rep. of Afghanistan, Letter dated Jul. 22, 1993 from the Permanent Rep. of Afghanistan to the United Nations addressed to the Secretary-General, U.N. Doc. S/26145 (Jul. 22, 1993).

218. Permanent Rep. of the Russian Federation to the United Nations, Letter dated Jul. 15, 1993 
noting that, "the moment has come when the international community as a whole must adopt a responsible and realistic approach towards those forces which flagrantly violate the norms of international law." 219 Russia thus deemed its right to self-defense valid independent of any responsibility of the Afghan state.

The major powers' response to these defensive actions was tepid. None of the UN political organs specifically objected to the joint Russian-Tajik military operations on Afghan territory. The Security Council called "for the cessation of all hostile actions on the Tajik-Afghan border," but it also reaffirmed the "necessity to respect the sovereignty and territorial integrity of Tajikistan." 220 The European Community issued a statement calling for "moderation" by all parties. ${ }^{221}$ The general acquiescence of key states to the Russian-Tajik action contrasts sharply with the international response to the Soviet Union's 1979 invasion of Afghanistan. It suggests that the 1993 action was lawful both in principle and practice.

\section{Turkey-Iran-Iraq}

Major powers and Israel have not been the only nations to premise selfdefense upon state weakness. Turkey and Iran have also claimed the right in response to the threats posed by non-state actors. The authorities in Baghdad have rarely, if ever, exercised effective control over the mountainous, Kurdishoccupied territory of northern Iraq, despite their repeated and brutal military campaigns in the region. ${ }^{222}$ Armed Kurdish nationalist groups, in particular the Kurdish Workers Party ("PKK"), have exploited this absence of control to establish bases of operation from which to launch attacks into Turkey and Iran. Prior to the 1991 Gulf War, the government of Saddam Hussein tacitly admitted its lack of control over northern Iraq and the threat this posed to its neighbors by creating a six-mile-wide joint Iraqi-Turkish security zone straddling the border and by consenting to repeated incursions by the Turkish military. ${ }^{223}$

from the Permanent Rep. of the Russian Federation to the United Nations addressed to the SecretaryGeneral, U.N. Doc. S/26110 (Jul. 15, 1993); Permanent Rep. of Tajikistan, Letter dated Aug. 5, 1993 from the Permanent Rep. of Tajikistan to the United Nations addressed to the Secretary-General, U.N. Doc. S/26241 (Aug. 5, 1993).

219. Id.

220. President of the Security Council, Note by the President of the Security Council, S/26341 (Aug. 23, 1993).

221. Permanent Rep. of Belgium, Letter dated Jul. 27, 1993 from the Permanent Rep. of Belgium to the United Nations addressed to the Secretary-General, U.N. Doc. S/26174 (Jul. 27, 1993).

222. See generally Robert Olson, The Kurdish Question in the Aftermath of the Gulf War, 13 THIRD WORLD Q. 475 (1993).

223. Id. at 489; Loren Jenkins, Turkish Kurds Fight Unheralded; Ankara Soft-Pedals War but Recent Clashes Hint at Wider Scope, WASH. Post, Oct. 12, 1986, at A22 (referring to confirmation by "Turkish officials" that Turkish military action in Iraq was conducted with the "approval of the Iraqi government"); Turkey Says Its Planes Raided Kurdish Guerilla Bases in Iraq, N.Y. Times, Mar. 5, 1987, at A9 (referring to a 1984 agreement between Turkey and Iraq permitting hot pursuit 
Following the Gulf War, Iraq withdrew its consent to external intervention and reasserted negative sovereignty. ${ }^{224}$ This claim of sovereignty was particularly striking given that Baghdad's control over the region had become even weaker following the establishment of the "no-fly" zone after the first Gulf War. Despite lack of consent by the authorities in Baghdad, Turkey and Iran continued to resort to force against Kurdish targets in northern Iraq. Both states invoked the Baghdad government's absence of control as a basis for their interventions in northern Iraq.

In 1995, Turkey launched Operation Steel, its most comprehensive military assault upon PKK targets located in the "no-fly" zone of northern Iraq. Turkey argued that its actions constituted legitimate measures of self-defense intended to prevent "the use of [Iraqi] territory for the staging of terrorist acts against Turkey." 225 Turkey's resort to force was necessary and hence lawful because Iraq had "not been able to exercise its authority over the northern part of its country since 1991."226 Moreover, Turkey emphasized that its operations were "of limited time and scope" and thus proportional. ${ }^{227}$ Despite Iraqi complaints of Turkish aggression to the Secretary-General and the Security Council, neither the General Assembly nor the Security Council met to discuss the issue, much less to take action on it. ${ }^{228}$ The United States expressed understanding for Turkish self-defense measures, ${ }^{229}$ though the United Kingdom and Germany questioned the proportionality of Turkish military actions and called for Turkey to "practice restraint." 230

In 1996, Iran advanced a similar justification for its own attacks on Kurdish targets in northern Iraq. In fulfilling its Article 51 reporting requirement, Iran argued that its use of force on Iraqi soil was "[i]n response to these encroachments by terrorist armed groups and in accordance with its inherent right of self-

of Turkish forces into Iraqi territory).

224. See, e.g., Permanent Rep. of Iraq to the United Nations, Letter dated Apr. 7, 1995 from the Permanent Rep. of Iraq to the United Nations addressed to the President of the Security Council, U.N. Doc. S/1995/272 (Apr. 7, 1995); Permanent Rep. of Iraq to the United Nations, Letter Dated Apr. 16, 1997 from the Permanent Rep. of Iraq to the United Nations addressed to the SecretaryGeneral, U.N. Doc. S/1997/318 (Apr. 16, 1997).

225. Charge d'Affaires A.I. of the Permanent Mission of Turkey to the United Nations, Letter dated July 24, 1995 from the Charge d'Affaires A.I. of the Permanent Mission of Turkey to the United Nations addressed to the President of the Security Council, U.N. Doc. S/1995/605 (July 24, 1995).

226. Id.

227. Id. at 1

228. FRANCK, supra note 192, at 63; Christine Gray, International Law and the Use of Force 117 (2008).

229. Associated Press, U.S. Backs Turkish Troop Move, N.Y. TIMES, Sept. 8, 1996, at A14 (citing remarks by Secretary of State Warren Christopher).

230. Chris Hedges, Turks Reported Likely to Keep Troops in Iraq for Weeks, N.Y. TIMES, Mar. 23, 1995, at A3. 
defense enshrined in Article 51 of the Charter." 231 Iran noted that the "Government of Iraq is not in a position to exercise effective control over its territory in the northern part of that country." 232 As a consequence, "transborder armed attacks and sabotage operations by terrorist groups against Iranian border towns, originating from Iraqi territory, have been intensified and escalated." 233 Thus, Iraq's lack of control over its territory necessitated Iran's "immediate and proportional measures." 234

As with the Turkish incursions, the United Nations took no action against Iran, despite Iraq's protests. ${ }^{235}$ The silence of the UN organs and other critical actors suggests continued acceptance of transnational force against non-state actors.

\section{F. Post 9/11: Continuity and Formalization}

\section{United States-Afghanistan}

Al Qa'ida's September 11, 2001, attacks upon the United States and the subsequent US invasion of Afghanistan confirmed the post-Charter vitality of an internationally recognized right to self-defense against non-state actors. Although some have argued that the attacks and their aftermath represent an "international constitutional moment" 236 with respect to the use of force against nonstate actors, 9/11 merely marked a more explicit recognition of a longstanding right. Previously, governments had often acquiesced to defensive action against non-state actors after the fact, but in the aftermath of 9/11 the international community legitimized defensive action in advance. The UN Security Council immediately condemned the atrocities as "attacks" which represented a "threat to international peace and security" and recognized the "inherent right of individual or collective self-defense in accordance with the Charter." 237 Notably, the Security Council did not attribute the threat to international peace and security to any state, evidenced in part by the fact that the resolution recognized a right to self-defense without reference to any state. 238

231. Permanent Rep. of Islamic Republic of Iran to the United Nations, Letter Dated 29 July 1996 from the Permanent Rep. of the Islamic Republic of Iran to the United Nations addressed to the Secretary-General, U.N. Doc. S/1996/602 (Jul. 26, 1996).

232. Id.

233. Id.

234. Id.

235. Permanent Rep. of Iraq to the United Nations, Letter dated August 1, 1996 from the Permanent Rep. of Iraq to the United Nations addressed to the Secretary-General, U.N. Doc. S/1996/617 (Aug. 1, 1996).

236. Slaughter \& Burke-White, supra note 18, at 1.

237. S.C. Res. 1368, pmbl. ๆ 1, U.N. Doc. S/RES/1368 (Sept. 12, 2001).

238. See Armed Activities on the Territory of the Congo (Dem. Rep. Congo v. Uganda), 2005 I.C.J. at 928 (separate opinion of Judge Kooijmans) ("I also observed that this interpretation no longer seems to be shared by the Security Council, since in resolutions 1368 (2001) and 1373 (2001) it recognizes the inherent right of individual or collective self-defense without making any reference to an armed attack by a State. In these resolutions the Council called acts of international terrorism, 
In reporting its subsequent military response to the Security Council, the United States invoked its "inherent right . . . to self-defense" against both "organizations and states." 239 Although the United States alleged that Al Qa'ida was supported by the "Taliban regime," the United States did not claim that the Afghan state (if it even existed) was responsible for the 9/11 attacks. Instead the United States took action against the "Al-Qaeda terrorist training camps and military installations of the Taliban regime in Afghanistan" but not against the Afghan state as such. ${ }^{240}$ Faced with the lethal threat of Al Qa'ida, the fact or fiction of the Afghan state and its responsibility were simply irrelevant to the issue of self-defense. ${ }^{241}$ Subsequent US military action in Afghanistan met with near universal approval.

\section{Russia-Georgia}

Russia's 2002 actions in Georgia illustrate that while major powers may agree in principle to the right to self-defense against non-state actors, they may differ on the application of this principle. Invoking the $9 / 11$ attacks, Russia argued before the Security Council in 2002 that the UN Charter must be applied in such a way as to accommodate the existence of ungoverned territories and transnational terrorists. ${ }^{242}$ In the context of its ongoing campaign against Chechen separatist and allied Islamist fighters, Russia argued that "[t]he continued existence in separate parts of the world of territorial enclaves outside the control of national governments, which, owing to the most diverse circumstances, are unable or unwilling to counteract the terrorist threat is one of the reasons that complicate efforts to combat terrorism effectively."243 Russia identified Georgia's Pankisi Gorge as one such ungoverned territory and maintained that it could lawfully use force against non-state actors operating from this region: "If the Georgian leadership is unable to establish a security zone in the area of the Georgian-Russian border . . . and does not put an end to the bandit sorties and attacks on adjoining areas in the Russian Federation, we reserve the right to act

without any further qualification and without ascribing them to a particular State, a threat to international peace and security").

239. Permanent Rep. of the United States of America, Letter dated Oct. 7, 2001 from the Permanent Rep. of the United States of America to the United Nations addressed to the President of the Security Council, U.N. Doc. S/2001/946 (Oct. 7, 2001).

240. Id.

241. See Armed Activities on the Territory of the Congo (Dem. Rep. Congo v. Uganda), 2005 I.C.J. at 9 28-29 (separate opinion of Judge Kooijmans).

242. It should be noted that over a year before the attacks of September 11, 2001, Russia warned the Taliban it was willing to take "preventative measures if necessary" if the Taliban did not cease sheltering and supporting Islamic rebels from Chechnya and the former Soviet Republics of Central Asia. See Michael R. Gordon, Russia warns Afghanistan not to aid rebel groups, N.Y. Times, May 25, 2000, at A7.

243. Permanent Rep. of the Russian Federation to the U.N., Letter dated Sept. 11, 2002 from Permanent Rep. of the Russian Federation to the United Nations addressed to the Secretary-General, U.N. Doc. S/2002/1012 (Sept. 11, 2002). 
in accordance with Article 51 of the Charter of the United Nations, which lays down every Member State's inalienable right of individual or collective selfdefense."244 Georgia's fecklessness necessitated Russia's use of force.

The United States responded by condemning the Russian incursions into Georgia but it did not reject the legal framework invoked by Russia. Rather, the United States argued that Russia's claim of self-defense was merely a pretext for pursuing other goals. The United States acknowledged that the Georgian government's lack of effective control over the Pankisi Gorge had permitted the presence of "foreign militants and international terrorists" who represented a threat to regional security. ${ }^{245}$ Nonetheless, unilateral Russian action was not justified because Georgia was making (with US military assistance) good faith efforts to "root out Chechen fighters and criminal and international terrorist elements. These efforts signal Georgia's commitment to restoring Georgian authority in the Pankisi Gorge and dealing seriously with international terrorists linked to al-Qa'ida." ${ }^{246}$ In contrast to Georgia's good faith efforts to "reassert control in the Pankisi Gorge", the United States suggested that Russia had acted in bad faith. The United States contended that the intervention was prompted in part by "Russia's displeasure with Georgia's commitment to the East-West energy transportation corridor" as well as "the fact that some in Russia viscerally dislike [then Georgian President Eduard] Shevardnadze."247 Russia's prior pattern of conduct towards Georgia also undermined Russia's legal claims. This pattern included "Russia's periodic cutting off of Georgia's winter gas supply, Russia's stalling of negotiations on political settlement in the break-away Georgian region of Abkhazia, and its delaying of negotiations to meet CFE Istanbul commitments for the withdrawal of Russian military forces still on Georgian territory." 248 Thus, the United States and Russia appear to agree on the legal principle but disagree on its application to the facts.

\section{Israel-Lebanon}

The legal arguments following Israel's 2006 invasion of southern Lebanon suggest further formal recognition of the security threat posed by state weakness and non-state actors as well as an acceptance of a right to self-defense. During July and August 2006, Israel engaged in a sustained aerial and ground assault upon targets in southern Lebanon in response to a transborder raid launched by Hezbollah. In complying with its Article 51 reporting requirement, Israel at-

244. Id.

245. Statement by B. Lynn Pascoe, Dept. Sec. State European and Eurasian Affairs, State Department (Sept. 27, 2002), available at http://www.america.gov/st/washfileenglish/2002/September/20020927155334fenner@pd.state.gov7.893008E-02.html.

246. Id.

247. Id.

248. Id. 
tributed responsibility for Hezbollah's raid to the Government of Lebanon. ${ }^{249}$ However, Lebanon's responsibility arose not from any affirmative act on its part. Rather, Israel attributed Lebanon's responsibility to the fact that the "ineptitude and inaction of the Government of Lebanon has led to a situation in which it has not exercised jurisdiction over its own territory for many years." 250 Therefore, Israel maintained that it had "the right to act in accordance with Article 51 of the Charter of the United Nations and exercise its right of self-defense when an armed attack is launched against a Member of the United Nations." 251

In response, Lebanon conceded that it lacked effective control over the territory in southern Lebanon in which Hezbollah was based, but suggested that such lack of control absolved it of responsibility. "The Lebanese Government was not aware of the events that occurred and are occurring on the international Lebanese border. The Lebanese Government is not responsible for these events and does not endorse them." 252 The Lebanese Government called upon the Security Council to take up the situation.

The resolution that the Security Council ultimately issued in response to this conflict is significant because it recognized Lebanon's ineffective control over its territory and implicitly legitimized Israel's claim of self-defense. More specifically, the Security Council acknowledged Israel's jus belli claim, accepting the basis for hostilities by emphasizing the "need to address urgently the causes that have given rise to the current crisis," 253 including the weakness of the Lebanese state and the strength of Hezbollah. The Security Council therefore called for the "Government of Lebanon . . . to extend its authority over its territory, through its own legitimate armed forces, such that there will be no weapons without the consent of the Government of Lebanon and no authority other than that of the Government of Lebanon." 254 The Council emphasized the need for "the extension of the control of the Government of Lebanon over all Lebanese territory ... [and] for it to exercise its full sovereignty, so that there will be no weapons without the consent of the Government of Lebanon and no authority other than that of the Government of Lebanon." 255 The resolution used similar language, calling for "the disarmament of all armed groups in Lebanon, so that . .. there will be no weapons or authority in Lebanon other than that of the Leba-

249. Permanent Rep. of Israel to the United Nations, Identical letters dated 12 July 2006 from the Permanent Rep. of Israel to the United Nations addressed to the Secretary-General and the President of the Security Council, U.N. Doc. S/2006/515 (Jul. 12, 2006).

250. Id.

251. Id.

252. Chargé d'affaires of the Permanent Mission of Lebanon to the United Nations, Identical Letters dated Jul. 13, 2006 from the Chargé d'affaires a.i. of the Permanent Mission of Lebanon addressed to the Secretary-General and the President of the Security Council, U.N. Doc. S/2006/518 (Jul. 13, 2006).

253. S.C. Res. 1701, U.N. Doc. S/RES/1701 (Aug. 11, 2006).

254. Id.

255. Id. 
nese State." ${ }^{256}$ Although the Security Council ultimately decided that the scope of Israel's military action was disproportionate, ${ }^{257}$ most of the key players (Israel, Lebanon and the Security Council) acknowledged the significant threat to security posed by state weakness and independent non-state actors such as Hezbollah, who exploit the lacuna between positive and negative sovereignty.

\section{Colombia-Ecuador}

As with the debate over Israel's strikes against Hezbollah, the international reaction to Colombia's raid upon targets in Ecuador is another case of major powers tacitly recognizing a right to cross-border defensive action against independent non-state actors. Colombia resorted to force in the context of a once internal armed conflict that had spilled over the country's borders as the government's non-state adversaries sought refuge in neighboring countries. ${ }^{258}$ As with the Soviet Union's incursion into Mongolia and Britain's raid into the United States, Colombia's raid into Ecuador targeted insurgent forces exploiting the ungoverned territory of a neighbor to mount attacks against a neighboring state. In this case, the guerillas were the Revolutionary Armed Forces of Colombia (FARC). On March 1, 2008, Colombian military forces responded by launching an aerial and ground assault upon a FARC base located on the Ecuadorian side of the border. The assault resulted in the death of Raul Reyes, a FARC commander, among others.

Colombia justified its incursion into Ecuadorian territory on the grounds that Ecuador "violated international norms which prohibit countries from harboring terrorists." 259 Colombian officials stressed that "the real issue is not that 'Raul Reyes' was in his pajamas and not in his military fatigues when he was killed; the issue is that he felt comfortable enough in his Ecuadorean base to feel that he could sleep in his pajamas. $" 260$ Ecuadorian officials conceded that their

256. Id.

257. The Security Council expressed "concern at the continuing escalation of hostilities in Lebanon and in Israel since Hizbollah's attack on Israel on 12 July 2006, which has already caused hundreds of deaths and injuries on both sides, extensive damage to civilian infrastructure and hundreds of thousands of internally displaced persons." Id.; See, e.g., Press Release, Secretary-General, Secretary-General Says 'Immediate Cessation of Hostilities' Needed in Lebanon, Describes Package Aimed at Lasting Solution, in Security Council Briefing, U.N. Doc. SG/SM/10570, SC/8781 (Jul. 20, 2006); See U.N. SCOR, 61st Sess., 5489th mtg. at U.N. Doc. S/PV.5489 (Jul. 14, 2006); U.N. SCOR, 61st Sess., 5493d mtg. at U.N. Doc. S/PV.5493 (July 21, 2006); Press Release, Council of the European Union, Main Results of the Council 2, 13 11575/06 (Presse 219) (Jul. 17-18, 2006), available at http://www.consilium.europa.eu (recognizing Israel's right to self-defense but calling for restraint from disproportionate action); see also Thomas M. Franck, On Proportionality of Countermeasures in International Law, 102 AM. J. INT'L L. 715, 732-734 (2008); WETTBERG, supra note 104, at 117-123 (describing international reaction to the Israeli invasion of Lebanon).

258. RABASA, supra note 13 (describing the FARC's refuges in border regions).

259. Press Release, Office of the President of Colombia (Mar. 3, 2008), available at http://web.presidencia.gov.co/sp/2008/marzo/03/01032008.html.

260. Staff of S. Comm. on Foreign Relations, 110th Cong., Playing With Fire: 
state was incapable of controlling its border region to exclude the FARC. ${ }^{261} \mathrm{Co}$ lombia later released information (substantiated by Interpol) indicating that FARC presence on Ecuadorian territory was not only the result of the lack of state capacity but also of active collusion. A document captured during the military raid contained an offer by an Ecuadorian official "to transfer police and army commanders in the area who proved hostile to the FARC."262 Despite outrage by Ecuador and its ally Venezuela and condemnation by the Organization of American States, neither the Security Council nor the General Assembly took any action regarding the attack.

\section{G. Summary of State Responses and International Reactions}

States have accepted, if not always endorsed, defensive actions against nonstate actors. They have deemed such interventions lawful when transborder uses of force are proportional and necessary. ${ }^{263}$ It appears to be irrelevant whether a host state is unwilling or unable to exclude violent transnational actors. Rather than lowering the bar for state attribution to negligence or strict liability standards (e.g., responsibility for harboring), many states recognize a right to selfdefense vis-à-vis non-state actors irrespective of host state responsibility.

The hostility of many states during decolonization to such defensive uses of force, particularly by the post-colonial entities and Communist states supporting non-state actors in the context of "wars of national liberations," 264 has waned as both these post-colonial entities and Russia have themselves become the targets of independent armed groups acting across international borders. This shift in the perceived security interest of post-colonial entities has occasioned a changed understanding of the use of force, as illustrated by Uganda's arguments in Armed Activities on the Territory of the Congo (Dem. Rep. Congo v. Uganda), 2005 I.C.J. 168 (Dec. 19).

IV.

\section{APPLYING CUSTOMARY PRINCIPLES}

A narrow, state-centric interpretation of the law of self-defense fails as a matter of policy and law. A state-centric regime does not strike the proper bal-

Colombia, Equador, And Venezuela, 5 (Comm. Print 2008).

261. Id. at 8 .

262. Patricia Markey, Colombia Says FARC Documents Show Correa Ties, ReUTERs, Mar. 3 , 2008, available at http:// www.reuters.com/article/newsMaps/idUSN0229738220080303 [hereinafter FARC Documents].

263. The ICJ has recognized that necessity and proportionality are customary limitations upon the use of defensive force. Military and Paramilitary Activities (Nicar. v. U.S.), 1986 I.C.J. at 194.

264. Reisman, Private Armies in a Global War System, supra note 48, at 252, 258 (discussing the embrace by Communist powers and Third World states of "private armies" as instruments of policy in wars of national liberation). 
ance between responding to legitimate security threats and restricting pretextual, bad faith uses of force.

Nor is a state-centric regime international law. In practice, many governments recognize power and threats as they actually exist. As demonstrated in Part III, governments have for centuries faced security threats posed by nonstate actors exploiting the lacuna between positive and negative sovereignty. In order to respond to these threats, states long ago developed principles regulating the transborder defensive use of force against non-state actors. The principles that emerged from the Caroline and similar incidents, namely necessity and proportionality, strike the proper balance between responding to legitimate security threats and restraining illegitimate and excessive force. ${ }^{265}$ State practice and opinio juris demonstrate that the right of self-defense against non-state actors exists in customary law irrespective of state involvement.

The following section details how the principles derived from these historic incidents should be operationalized to regulate future uses of force against nonstate actors in order to vindicate the central policy aim of minimizing violence and promoting stability.

The key parameters of this framework are:

1) (Ir)relevance of consent

2) Establishing necessity

3) Geographic restrictions upon resort to force against a non-state actor

4) Differentiation between state and non-state actors

5) Temporal scope of recourse to force against non-state actors

\section{A. Consent: Desirable, Not Dispositive}

As a matter of policy, the consent of a host state may be desirable prior to the recourse to force against a non-state actor on its territory. As a matter of law, however, such consent is not dispositive as to whether a state may resort to defensive force.

\section{Policy}

From a policy perspective, the consent of the host state to defensive measures against non-state actors on its territory is desirable. The US targeted killing program in Pakistan illustrates the benefits of such consensual intervention. ${ }^{266}$ The host state may provide logistical and intelligence support for defen-

265. See Armed Activities on the Territory of the Congo (Dem. Rep. Congo v. Uganda), 2005 I.C.J. (separate opinion of Judge Kooijmans); Jennings, supra note 142.

266. Although Pakistan has not publicly consented to United States use of force on its territory, there is compelling evidence that lethal operations are undertaken on Pakistani territory with consent from the highest levels of the Pakistani government. In the fall of 2008, the New York Times reported that an Obama administration official said that " ... [n]o tacit agreement had been reached to allow increased Predator [drone] strikes [in Pakistan] in exchange for a backing off from additional American ground raids" referring to a September 3, 2009, raid by United States Special Operations 
sive action. For example, Pakistan allows the United States to dispatch unmanned aerial vehicles (UAVs) from its Shamsi airbase in Baluchistan against targets in the Federally Administered Tribal Areas. ${ }^{267}$ Yemen and Pakistan also provide the CIA with human intelligence that drives at least some of the targeting by these UAVs. ${ }^{268}$

Further, consensual intervention avoids the possible escalation of a conflict between the defending state and the non-state actor into an international armed conflict between the defending state and the host state.

As desirable as consent may be, the consent of the host state may not always be forthcoming or may be restricted in scope. The above example of Pakistan is also illustrative of the problematic nature of host state consent. Specifically, the scope of Pakistan's consent is limited insofar as the interests of US and Pakistani authorities diverge, as described in the paragraph below.

First, the foreign military intervention on Pakistani territory undermines the domestic legitimacy of the regime in Islamabad. The most obvious consequence of this legitimacy concern is the failure of Islamabad to formally acknowledge that UAV strikes are conducted with its consent. Instead, Pakistani authorities continue to issue increasingly implausible denials and pro forma protests over violations of Pakistani "sovereignty." 269 Pakistani concern over domestic legitimacy limits the scope of US action by restricting UAV strikes to "boxes" that include the Tribal Areas but exclude cities such as Quetta, Taliban leader Mullah Mohhamed Omar's base in Pakistan. ${ }^{270}$ Concerns over plausible deniability

personnel into Pakistan. See Mark Mazzetti \& Eric Schmitt, U.S. Takes to Air to Hit Militants Inside Pakistan, N.Y. TIMES, Oct. 27, 2008, available at https://www.nytimes.com/2008/10/27/washington/27intel.html [hereinafter U.S. Takes to Air]. According to the story, "[P]akistani officials have made clear in public statements that they regard the drone attacks as a less objectionable violation of Pakistani sovereignty." Id. Subsequent media reports claim that many of the American drone strikes originate from a base in Pakistan and that their increased frequency is the result of a March 2009 deal between the United States and Pakistan, which provides Pakistanis greater control of the targets. See James Kitfield, Wanted: Dead, NATIONAL JOURNAL, Jan. 9, 2010, at 6 (“'ff]or domestic political consumption, Pakistan's leaders promote the image of CIA agents flying drones from its American headquarters, but the program clearly involves a high degree of involvement by Americans inside Pakistan, and by the Pakistani government").

267. Jeremy Page, Google Earth Reveals Secret History of U.S. Base in Pakistan, THE TIMES, Feb. 19, 2009, available at http://www.timesonline.co.uk/tol/news/world/asia/article5762371.ece.

268. Kitfield, supra note 266; Mark Mazzetti, Eric Schmitt \& Robert Worth, Two-Year Manhunt Led to Killing of Awlaki in Yemen, N.Y. TIMES, Oct. 1, 2011, available at https://www.nytimes.com/2011/10/01/world/middleeast/anwar-al-awlaki-is-killed-in-yemen.html (describing coordination between Yemeni and American forces in the hunt for Anwar al-Awlaki).

269. Baqir Sajjid Syed, Drone Strikes a Violation of Sovereignty, Says FO, THE Dawn, Oct. 07, 2010, available at http://news.dawn.com/wps/wcm/connect/dawn-contentlibrary/dawn/news/pakistan/04-no-justification-for-drone-strikes-fo-qs-07 (Pakistani newspaper quoting a spokesman for Pakistan's Foreign Office as characterizing drone strikes as a "violation of our sovereignty" and denying that they are conducted pursuant to any "understanding" with the United States).

270. Greg Miller, U.S. Wants to Widen Area in Pakistan Where It Can Operate Drones, WASH. 
also appear to underlie Pakistan's refusal to allow actions by American Special Operations forces against Al Qa'ida fighters on its territory, such as the SEAL raid against Osama Bin Laden in Abbottabad. ${ }^{271}$

Second, as a result of Pakistan's divergent strategic interests from the United States, Pakistan considers certain non-state actors to be assets, whereas the United States regards these same actors to be threats. For example, Pakistan considers both the Quetta Shura and the Haqqani Network to be assets for achieving strategic depth in Afghanistan vis-à-vis its archrival India, notwithstanding their ties to Al Qa'ida and their continued attacks upon US and Afghan forces. ${ }^{272}$ In light of these broader interests, Pakistani cooperation with US efforts in Afghanistan has been less than complete.

\section{Law}

As a matter of international law, the consent of a host government, whether Pakistani or Yemeni, is not dispositive. The United States may, under customary international law, resort to force against Al Qa'ida and associated non-state actors on Pakistani or Yemeni territory, with or without the consent of these governments.

Two of the incidents analyzed in Part III illustrate that under customary international law, states enjoy a right of self-defense vis-à-vis non-state actors irrespective of the consent of the host state. ${ }^{273}$ Both the United States' 1916 expedition into Mexico against Pancho Villa and Turkey's 1995 intervention against Kurdish militias in northern Iraq were initially premised upon the consent of the host state. However when the host states withdrew their consent, both the United States and Turkey continued to take defensive measures against the non-state actors and justified these as self-defense. ${ }^{274}$ In light of the international response, the lawfulness of Turkey's defensive measures in Iraq is particularly clear. Despite Iraq's protests, international reaction ranged from understanding to muted concern over proportionality.

Post, Nov. 20, 2010, available at http://www.washingtonpost.com/wpdyn/content/article/2010/11/19/AR2010111906268.html?hpid=topnews\&sid=ST2010111905681 (describing Pakistan's rejection of expanded drone strikes over several concerns, including a popular backlash).

271. U.S. Takes to Air, supra note 266. According to the story, "[P]akistani officials have made clear in public statements that they regard the drone attacks as a less objectionable violation of Pakistani sovereignty."

272. Jane Perlez, Eric Schmitt \& Carlotta Gall, Pakistan is Said to Pursue Foothold in Afghanistan, N.Y. TIMES, Jun. 24, 2010, available at http://www.nytimes.com/2010/06/25/world/asia/25islamabad.html (describing Pakistani efforts to gain influence in Afghanistan through non-state proxies); John R. Schmidt, Pakistan's Alternate Universe, FOREIGN POLICY, Oct. 18, 2011, available at http://www.foreignpolicy.com/articles/2011/10/18/pakistan_haqqani_network_us_relations.

273. Finch, supra note 173; Olson, supra note 222.

274. Olson, supra note 222. 
In the context of the United States' use of force in Pakistan, the lawfulness of the UAV strikes, Special Operations missions, or other measures against Al Qa'ida or associated groups is not contingent upon either the existence or scope of the Pakistani government's consent. The United States may lawfully resort to force against non-state actors in Pakistan-or Yemen or Somalia—on the independent basis of self-defense.

\section{B. Establishing Necessity}

Having established that consent is not required for lawful self-defense, what $i s$ required for lawful self-defense? This threshold inquiry regarding the unilateral use of force against a non-state actor is one of necessity. Such force is lawful only when it is necessary, leaving "no choice of means." ${ }^{275}$ Necessity exists when alternative means of neutralizing a security threat are inadequate.

The necessity of self-defense turns on the reality of the threat posed by non-state actors, as well as the ability and willingness of their host states to take action against them. The host state's ability to abate the threat hinges upon the host state's effective control of its territory. In a fictitious state, where the central authorities have relinquished or simply failed to consolidate their monopoly over violence, recourse to transborder force may be the only means of abating the threat. As the British authorities observed in the Caroline incident, recourse to feckless or indifferent authorities in such circumstances would be futile. ${ }^{276}$

Thus, when the territorial state hosting a violent non-state actor is willing and able to adequately address the threat, the unilateral use of force will be unnecessary and hence unlawful. The availability of alternative means such as diplomatic entreaty or extradition would thus render self-defense unlawful. If the host state is unable or unwilling to address the threat, the use of defensive force is necessary and hence lawful. ${ }^{277}$

The intervening state carries the burden of establishing that alternative remedies such as diplomatic entreaties and law enforcement measures are insufficient to abate the threat posed by non-state actors operating from the territory of another state. Absent such a showing, the unilateral recourse to transborder force is presumptively unlawful.

A few examples illustrate this point. The Russian incursions into Georgia's Pankisi Gorge in 2002 were unnecessary and hence unlawful. As described above, at the time the US military was assisting Georgian authorities in countering the same Chechen threat to which Moscow claimed to be reacting. Notwithstanding Russian declarations to the contrary, Georgia was in fact confronting

275. Jennings, supra note 142 , at 82 (citing H. Ex. Doc. No. $74,25^{\text {th }}$ Cong., $2^{\text {nd }}$ Sess.).

276. Id. at 90 .

277. See Ashley S. Deeks, Pakistan's Sovereignty and the Killing of Osama Bin Laden, AM. SOC'Y OF INT'L LAW INSIGHTS (May 5, 2011), available at http://www.asil.org/pdfs/insights/insight110505.pdf. 
the non-state actors within its territory.

In contrast, necessity exists when entreaties to the authorities of the host state would be counterproductive to the suppression of the security threat. For example, Colombia presented evidence of collusion between Ecuadorian authorities and the FARC in the case of Colombia's raid against Raul Reyes' camp inside Ecuador. ${ }^{278}$ Colombia argued that requests to the Ecuadorian authorities only would have afforded FARC advance warning.

The United States adopted a similar position with respect to the SEAL raid upon Abbottabad. The United States did not to notify the authorities in Islamabad prior to the raid, much less seek their consent, because of concerns over collusion between elements of the Pakistani security services and Al Qa'ida. ${ }^{279}$

\section{The Geographic Scope of the Use of Force Against a Non-State Actor}

Necessity establishes not only when a defending state may resort to force against a non-state actor, but also where the defending state may act. Put differently, necessity defines the legal limits of the battlefield in a non-international armed conflict. Establishing the boundaries of this battlefield is especially crucial in conflicts involving diffuse and loosely organized entities such as Al Qa'ida or highly mobile actors such as Lord's Resistance Army, which operate in the ungoverned territories of multiple countries. As illustrated by the controversy over the "Global War on Terror" and especially the United States' ongoing program of targeted killings via missile strikes from UAVs, such boundaries are needed. ${ }^{280}$

Armed conflict is not football. Both with respect to fact and law, the physical boundaries of the playing field in an armed conflict are not permanently fixed prior to the onset of action. Contrary to the assertion of the UN Special Rapporteur on Extrajudicial Killings, the boundaries of an armed conflict are not determined by the law of armed conflict or the prior occurrence of hostilities in a given region. 281

Rather, the boundaries of where a state may resort to force are defined by long standing principles of jus ad bellum and the location of hostilities. Although not usually couched in these terms, what defines the lawful battlefield is the principle of necessity. The region of conflict is that area where a state may lawfully resort to force against a state or non-state actors. Only in the region of

278. FARC Documents, supra note 262.

279. Alan Cowell, Pakistan Sees Shared Intelligence Lapse, N.Y. Times, May 4, 2011, available at https://www.nytimes.com/2011/05/05/world/asia/05react.html (noting that Pakistani officials are angry about CIA director Leon Panetta's claim that the United States did not inform Pakistani officials in advance of the raid because it might have leaked, allowing Bin Laden to escape).

280. See Gabor Rona, Interesting Times for International Humanitarian Law, 27 FLETCHER F. WORLD AFF. 55, 61 (2003).

281. Philip Alston, Report of the Special Rapporteur on Extrajudicial and Summary Executions, $\uparrow \uparrow 18-19$, U.N. Doc. A/HRC/14/24/Add.6 (May 28, 2010). 
conflict may a state lawfully violate the sovereignty of other states.

Defining the region of conflict on the basis of necessity comports with the traditional rules regulating the belligerency or neutrality of states during interstate conflict. During interstate armed conflict, neutral states enjoy a right of territorial inviolability vis-à-vis belligerent states. ${ }^{282}$ However, respect by the belligerents of the neutral's negative sovereignty is contingent upon the fulfillment of corresponding duties. Neutral states must not allow the movement of belligerent troops or military materiel across its territory. ${ }^{283}$ Should belligerent troops enter the territory of a neutral state, that state is required to intern the troops. ${ }^{284}$ Neutral states are also under an obligation to prevent the formation or recruitment of belligerent military units upon its territory. ${ }^{285}$

The logic of these well-established rules of interstate conflict applies equally to conflicts involving non-state actors. The lawfulness of a belligerent state's violation of a neutral state's territory hinges upon the reality of the threat and whether the neutral state has or will take adequate measures to abate this threat. When due to incompetence or connivance a neutral state fails to incapacitate a violent non-state actor on its territory, it jeopardizes its negative sovereignty. The neutral state's territory may become part of the lawful region of the conflict.

Applying this rule to the United States' current conflict with Al Qa'ida reflexively imposes limits upon the scope of the "Global War on Terror." With respect to the US targeted killing program, killings within the territory of a host state are lawful where the central authorities are on notice and have failed to intern Al Qa'ida fighters. Therefore, the use of force in violation of the host state's negative sovereignty would be lawful in Pakistan's Federally Administered Tribal Areas, Somalia, or the Yemeni hinterland. ${ }^{286}$ In contrast, a missile strike from a UAV against an Al Qa'ida member on the streets of London (even with zero collateral casualties) would be unlawful. Such action would be an unnecessary violation of the United Kingdom's negative sovereignty because the British

282. Hague Convention (V) Respecting the Rights and Duties of Neutral Powers and Persons During War on Land, art. 1. Oct 18, 1907 [hereafter Hague Convention].

283. Id. at arts 2,5 .

284. Id. at art. 11.

285. Id. at arts. 4,5 .

286. See StafF OF S. Comm. Relations, 111 Th Cong., Al Quaeda In YemEn and Somalia: A Ticking Time Bomb, 3, 8, (Comm. Print 2010) ("Both Yemen and Somalia have weak central governments that exercise little or no control over vast swaths of their own territory and forbidding, harsh terrains that would make it virtually impossible for U.S. forces to operate freely. They have abundant weapons and experience using them on the battlefield .... As Al Qaeda members continue to resist U.S. and Pakistani forces along the Afghanistan-Pakistan border, some of their comrades appear to be moving to Yemen and Somalia, where the political climate allows them to seek safe haven, recruit new members, and train for future operations. ... There are parallels between Pakistan and Yemen, according to U.S. counter-terrorism officials, military leaders, and policymakers. Both have become havens for significant numbers of Al Qaeda fighters formerly active in Afghanistan. Both have weak central governments that have difficulty controlling vast swaths of their own territory and populations that are often hostile to the United States"). 
authorities are willing and able to incapacitate Al Qa'ida fighters on their soil. The Tribal Areas and Yemen are within the region of conflict, but London is not.

In summary, necessity defines the outer geographical boundaries of the region of conflict. If a defending state can counter a non-state threat in a given area by means other than unilateral force, such as diplomatic entreaty, then that area lies outside the region of conflict. Thus, for example, necessity would establish the geographic limits of the war on terror.

\section{Differentiation vs. Attenuated State Responsibility}

The principles of necessity and proportionality dictate not only whether and where a state may resort to force against non-state actors, but also how. These principles favor differentiating between non-state actors and the personnel and infrastructure of their host states. Necessity and proportionality militate against premising the defensive use of force upon an expanded scope of host state responsibility for the acts of private armed groups. ${ }^{287}$ Expanded responsibility holds the host state to a standard of negligence ${ }^{288}$ or strict liability. ${ }^{289}$ Basing self-defense upon expanded host state responsibility reflects a state-centric view that fails to account for the reality of how power and control actually exist. While a fictitious state may act wrongfully and breach an international duty for which it is liable for restitution, as a matter of law and policy a distinction should be drawn being wrongful behavior and dangerous conduct.

When a truly independent non-state actor threatens a state, the necessity of the use of force relates solely to the non-state actor, not to the territorial host state. Targeting the infrastructure or personnel of the host state is unlawful because it is unnecessary and disproportionate.

Failure to differentiate between the state and the non-state actor will usually render unilateral defensive action unlawful. For example, in its 2006 military campaign in Lebanon, Israel failed to differentiate between its non-state adversary, Hizbollah, and the Lebanese state, as evidenced by the Israeli destruction of the Beirut airport and extensive civilian casualties. ${ }^{290}$ This disproportionate use of force, unrelated to the security threat posed by Hizbollah, rendered the

287. See Derek Jinks, State Responsibility for the Acts of Private Armed Groups, 4 CHI. J. INT'L L. 83 (2003) (arguing against relaxing the standards for state responsibility).

288. See National Security Strategy, supra note 10, at 5 ("We make no distinction between terrorists and those who knowingly harbor or provide aid to them").

289. Vincent-Joel Proulx, Babysitting Terrorists: Should States be Strictly Liable for Failing to Prevent Transborder Attacks?, 23 BERKELEY J. INT'L L. 615 (2005) (arguing for the strict liability of the territorial state).

290. Israel Imposes Lebanon Blockade, BBC NEwS, Jul. 13, 2006, available at http://news.bbc.co.uk/2/hi/middle_east/5175160.stm; Jan Egeland, Deliberate Destruction or "Collateral Damage"? Israeli Attacks on Civilian Infrastructure, Amnesty International (Aug. 2006), available at http://www.amnesty.org/en/library/asset/MDE18/007/2006/en/4a9b367a-d3ff-11dd8743-d305bea2b2c7/mde180072006en.pdf. 
Israeli invasion unlawful as a matter of jus ad bellum. ${ }^{291}$

There should be a strong presumption that necessity and proportionality require differentiation between state and non-state personnel and infrastructure, and that the occupation of territory is presumptively unlawful. Nonetheless, abating some persistent security threats may require expansive intervention and territorial occupation. In order to deny violent non-state actors a sanctuary, a fundamental reordering of local conditions may be necessary where these actors represent a chronic threat. Such interventions could take the form of a temporary protectorate, such as President Buchanan proposed for northern Mexico. In extreme cases, changing the regime in the capital of the fictitious state may be necessary to prevent the return of the threatening non-state actor. Thus, the installation of the Northern Alliance in Kabul after 9/11 was necessary to establish a local ally in Afghanistan willing to suppress the persistent threat from Al Qa'ida. The dictates of necessity and proportionality are highly fact-specific and "can ultimately be subjected only to that most comprehensive and fundamental test of law, reasonableness in a particular context." 292

Differentiation based on necessity and proportionality, in contrast to attenuated state responsibility, also serves to promote global stability more generally. Although it is not the default form of political organization, the effective state is still the best entity to provide basic public goods, especially domestic security. Whereas fictitious states may occasionally imperil their neighbors through spillover, state weakness poses a much greater threat to the inhabitants of the fictitious state's own territory. The DRC illustrates the problem, as millions of Congolese civilians have died in the violence and disruption resulting from their state's weakness. By distinguishing between whatever weak, inchoate, or embryonic state may exist within a territory and the threatening non-state actor, defending states can preserve incipient order within a territory. Differentiation between the infrastructure and personnel of the nominal state and the non-state actor preserves order while real security threats are addressed. Such differentiation would precede the distinction between lawful and unlawful targets undertaken in accord with principles of jus in bello.

Underlying differentiation is an analytical distinction between wrongful conduct and dangerousness. Although a fictitious state may act wrongfully and

291. Qatar characterized Israel's use of force as beyond its stated objective, given the civilian nature of the Israeli targets. U.N. SCOR, 61st Sess., 5493d mtg. at 14, U.N. Doc. S/PV.5493 (Jul. 21, 2006). Lebanon clearly rejected Israel's contention to be acting primarily against non-State terrorist targets. It has been very clear from the beginning that it was not Hezbollah that was the target. It was Lebanon that was the target. Infrastructure was targeted and hundreds of civilians were killed before Israel even took up any campaign against Hezbollah and its positions. Id. at 6 . The Secretary General also characterized Israel's use of force as collective punishment of the Lebanese people. See U.N. SCOR, $61^{\text {st }}$ Sess., $5492^{\text {nd }} \mathrm{mtg}$. at 3, U.N. Doc. S/PV.5492 (Jul. 20, 2006). Argentina qualified Israel's use of force as collective punishment. U.N. SCOR, 61st Sess., 5493d mtg. at 9, U.N. Doc. S/PV.5493 (Jul. 21, 2006).

292. Myres S. McDougal \& Florentino P. Feliciano, Legal Regulation of Resort to International Coercion: Aggression and Self-Defense in Policy Perspective, 68 YALE L. J. 1057, 1132 (1959). 
breach a duty under international law by failing to suppress independent armed forces on its territory, it is not the state itself that poses the threat. Prior to the UN Charter, a victim state could have resorted to war to redress wrongs it had suffered as a consequence of the fictitious state's breach. ${ }^{293}$ Yet such retributive war was distinct from self-defense, which focused exclusively upon the threat posed by the non-state actor. This distinction is evident in the nineteenth century diplomatic correspondence of the United States. As Secretary of State Forsyth observed, American military intervention against marauders in Mexico, "[r]ests upon principles of the law of nations, entirely distinct from those on which war is justified - upon the immutable principles of self-defense - upon the principles which justify decisive measures of precaution to prevent irreparable evil to our own or to neighboring people." 294 Forsyth argued that such "decisive measures of precaution" that solely targeted the marauders were preferable over a war against Mexico over Mexico's irresponsibility. ${ }^{295}$

The great contribution of the UN Charter regime to world public order was the proscription of casus belli other than self-defense. Recourses to force premised upon attenuated state responsibility are responses to wrongful conduct and not necessarily an imminent threat. The use of force premised upon the breach of an international duty, rather than in response to a direct threat, erodes the restriction of jus ad bellum to self-defense.

\section{E. Temporal Scope: Armed Attack as Evidentiary Standard}

The principle of necessity should also inform the much debated "armed attack" requirement of Article 51. The armed attack requirement (if it exists) has particular significance with respect to violent non-state actors, such as $\mathrm{Al}$ Qa'ida, who are not susceptible to the traditional logic of deterrence. ${ }^{296}$ Precisely what uses of force constitute an "armed attack" and whether or not such an attack is the sine quo non of self-defense are hotly contested, in particular whether the right to self-defense applies against independent non-state actors

293. OPPENHEIM, supra note 46, at 67 (stressing recourse to war to vindicate rights: "A State may be driven into war because it cannot otherwise get reparations for an international delinquency, and may then maintain that it exercised by war nothing else than legally recognized self-help"); Brownlie, supra note 19 at 20-22 (describing war as a "means of obtaining redress in the absence of a system of international justice and sanctions").

294. MOORE, supra note 30, at Vol. 2, 420.

295. Id. at 420-421; see also OPPENHEIM, supra note 46, at 67 (stressing recourse to war to vindicate rights: "A State may be driven into war because it cannot otherwise get reparations for an international delinquency, and may then maintain that it exercised by war nothing else than legally recognized self-help").

296. Some groups, such as Hezbollah, which function as unrecognized de facto states may be more amenable to the territorial logic of deterrence. See Nadim Ladiki, Hezbollah Gives Israel More Clues in Strategy, REUTERS, Nov. 5, 2007, available at http://www.reuters.com/article/idUSL05623345 (noting that Hezbollah leader Hassan Nasrallah "said shortly after the [2006] war that he would not have ordered the attack had he known the Israeli retaliation would be so fierce"). 
and whether actions variously termed preventative, precautionary, preemptive, anticipatory, or interceptive self-defense are lawful. ${ }^{297}$

Article 51 should be interpreted in the context of the motivating purpose of the UN Charter, in a way as to reconcile it with the prior and subsequent customary law of self-defense, and that restrains the use of force while allowing for legitimate security measures. Read in this fashion, the armed attack requirement of Article 51 provides an objective basis for the determining validity of a claim of self-defense. 298

However, because wrongfulness is no longer a causus belli, an armed attack should not be read as evidence of a requirement of prior trespass, but rather as evidence of a threat. As noted in 1838 by the legal officers of the British Foreign Office with respect to the Caroline incident, the defensive use of force in response to an attack is justified not by the attack's wrongfulness, but by the threat it evinces. Such a response is "necessary as a measure of precaution for the future and not as a measure of retaliation for the past. What has been done previously is only important as affording irrefutable evidence of what would occur afterwards." 299

A focus on the necessity of defense against future attacks rather than the wrongfulness of prior injury suggests a general standard that fulfills the evidentiary function of an armed attack. ${ }^{300}$ An objective reasonableness standard premised on propensity and capability balances the dangers of false positives and false negatives. Such a standard provides for good-faith security measures while restricting pretextual intervention. ${ }^{301}$ Yet, its workability applied to either state or non-state actors is completely contingent upon the quality of intelligence regarding the intentions and capabilities of violent actors, a fact painfully illustrated by the 2003 invasion of Iraq.

$\mathrm{V}$.

\section{CONCLUSION}

This Article has described the reality of fictitious statehood, the persistent security threat posed by non-state actors exploiting this fiction, and the forceful

297. See, e.g., The Charter of the United NAtions: A COMmentary 794 (Bruno Simma et al. eds, 2 d ed. 2002); W. Michael Reisman \& Andrea Armstrong, The Past and Future of the Claim of Preemptive Self-defense, 100 AM. J. INT'L L. 525 (2006); High-level Panel on Threats, Challenges and Change, Report of the High-level Panel on Threats, Challenges and Change, A More Secure World: Our Shared Responsibility, U.N. Doc. A/59/565 (Dec. 2, 2004); Sean D. Murphy, The Doctrine of Preemptive Self-Defense, 50 VILL. L. REV. 699 (2005).

298. See C.M.H. Waldock, The Regulation of the Use of Force by Individual States IN INTERNATIONAL LAW 451, 463-464 (Recuil des Cours 2nd ed. 1952).

299. Jennings, supra note 142 , at 87.

300. But see, BROWNLIE, supra note 19, at 275-80 (arguing Article 51 to require prior trespass).

301. See Matthew C. Waxman, The Use of Force Against States that Might Have Weapons of Mass Destruction, 31 Mich. J. INT’L L. 1 (2009). 
response of states to this threat. In describing a number of episodes of selfdefense involving weak states and non-state actors, this Article has situated current US military operations against Al Qa'ida in their proper historic context. The pre-Charter principles illustrated by these incidents remain relevant and can be used to structure future defensive measures.

However, the challenges for international order posed by the gap between the theory and practice of statehood are much broader than the aspect explored in this Article. Consequently, there is a larger body of international law that bridges the gap between the theory and reality of statehood by accommodating the fact of state weakness. This body of law will continue to develop despite the persistent enthusiasm of some for nation building. There are no ready "fixes" for fictitious states. 